\title{
新規有機合成方法論の開発と有用化合物合成への展開
}

\author{
徳 山英利
}

\section{Development of New Synthetic Methods and Their Application to Synthesis of Useful Compounds}

\author{
Hidetoshi TOKUYAMA \\ Graduate School of Pharmaceutical Sciences, PRESTO, The Japan Science and Technology Corporation \\ (JST), The University of Tokyo, 7-3-1 Hongo, Bunkyo-ku, Tokyo 113-0033, Japan
}

(Received September 2, 2003)

\begin{abstract}
Development of novel synthetic methodologies and their application to synthesis of natural products are described. The first topic is about an extension of the scope of our indole synthesis by radical cyclization of $o$-alkenylphenyl isocyanides. By utilizing this methodology and nitrogenzenesulfonamide chemistry, an efficient total synthesis of hexacyclic aspidosperma indole alkaloid, aspidophytine, was accomplished. As the second generation indole synthesis, we then developed the method by radical cyclization of $o$-akenylthioanilides. Synthetic utility of this method was fully demonstrated by a total synthesis of iboga alkaloid, catharanthine. Furthermore, a total synthesis of vinca alkaloid, vinblastine through a practical synthesis of vindoline was achieved, in which the stereochemistry of the crucial coupling reaction of two indole fragments could be completely controlled. In addition to the indole chemistry, exceptionally mild transformations of thiol esters to ketones and alkenyl ketones have been developed. Examples of application of the protocols for the synthesis of natural products are also described.
\end{abstract}

Key words_—indole synthesis; thiol esters; total synthesis; indole alkaloids; aldehydes; ketones

\section{はじめに}

これまで天然物の全合成研究は，天然から見い出 された化合物の構造決定, 新しい有機反応を開発す るためのプラットホームとして，また，新しく開発 した反応の能力を試すためのテストケースとしての 役割を担ってきた。その結果，長年に渡る優れた反 応開発の成果の蓄積により, 今やどんな複雑な化合 物でも労力をかけさえすれば巧みに合成できるよう になったと言われている。しかしながら，最近では それらに加えて，2つの側面から質的向上が望まれ ている. 1 つは，量的な物質供給を可能にする合成 であり，もう 1 つは，生成物の diversityをもたら す合成である。数ミリグラムの化合物をようやく合 成できるという現状では，これらの点を満足するに は程遠い状況である。 その実現には，短工程で効率 的な合成ルートのデザインのみならず, 多種多様な

東京大学大学院薬学系研究科, さきがけ研究 21一科学 技術振興事業団（干113-0033 文京区本郷 7-3-1)

e-mail: tokuyama@mol.f.u-tokyo.ac.jp

*本総説は, 平成 15 年度日本薬学会奨励賞の受賞を記 念して記述したものである.
誘導体を合成可能なフレキシビリティーが高くかつ 官能基の共存性の高い合成反応の開発が必要であ る、本稿においては，筆者らがこれまで取り組んで きた，インドール合成法とチオールエステルを用い たアルデヒド，ケトンの合成法について述べ，それ らを用いた天然物合成への応用について紹介したい。

1. 新規インドール合成法の開発とインドールア ルカロイド合成への展開

1-1. イソニトリルを用いたインドール合成法の 新展開ここれまで, 天然から数多くの興味深い生 理活性を示すインドール化合物が見い出されてい る. 医薬開発においても, リード化合物としてのイ ンドール誘導体の重要性はいまだ変わらない。その ような背景のもとで，インドール骨格の合成研究は, 1883 年に Emil Fischer によって Fischer 合成法が見 い出されて以来, 現在まで数多くの合成法が報告さ れている. 1) しかし，複雑化する標的分子を効率的 に合成するためには, 一般性が高く, より穏和な条 件で進行する新規反応の開発が求められている.

筆者らのグループでは，2- アルケニルフェニル 
イソシアニド誘導体のラジカル環化反応を用いたイ ンドール合成法を既に開発している (Scheme 1). ${ }^{2)}$ すなわち，フェニルイソシアニド $(\mathbf{1})$ をスズヒドリ ドによるラジカル反応条件に付すと，イミドイルラ ジカル (2)を経て，2-スタニルインドール (3) が生 成する。ここで酸性処理を行うと 3- 置換インドー ル 4 が得られる。一方，そのまま one-pot での Pd 触媒を用いたカップリング反応に付すと，様々な 2,3-二置換インドール (5)を合成できる．本反応の 有用性はビンカディフォミン, 3) タベルソニン, ${ }^{3)}$ ビ ンドリン4)などのインドールアルカロイド合成への 応用により示されている. ${ }^{5,6)}$ 今回, 本手法のさらな る汎用性の向上を目的として，インドール前駆体で ある 2-アルケニルフェニルイソシアニドの新規合 成法の開発，及びインドール骨格構築後の置換基の 導入法に関して検討を加えた。

インドール前駆体の合成法としては，オルトヨー ドアニリン誘導体に対する Heck 反応によりアルケ ニル基を導入するか，又は薗頭反応によりいったん フェニルアセチレン誘導体を得たあとに部分還元に よってオレフィンへと変換する手法があるが，合成 できる置換様式が限られていた，そこで，より一般 性の高い手法として，フェニルイソシアニド部位を 有する Horner-Emmons 試薬 (6) の開発を行った. ${ }^{7)}$ これにより，アルデヒド，ケトンとの Horner-Emmons 反応を行うことで幅広いインドール前駆体の 簡便な合成が可能になつた。

6 の合成は，まず，2-ニトロベンズアルデヒド 7 をヒドロキシフォスホネート 8 に変換し, 接触還元
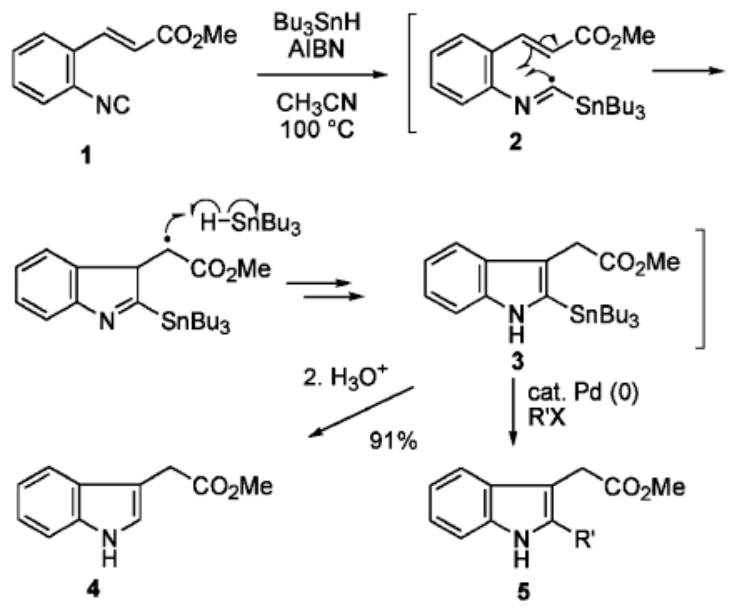

Scheme 1. Indole Synthesis with 2-Alkenylphenyl Isocyanide
条件下，ニトロ基の還元とベンジル位水酸基の還元 的除去を行った. 続いて, 常法にしたがってニトロ 基をイソニトリルへと変換し，望みの Horner-Emmons 試薬 (6) を短工程かつ高収率で合成すること ができた（Scheme 2)，本化合物とアルデヒド，ケ トンとの Horner-Emmons 反応はイソニトリルに由 来する副反応を伴わずに進行し様々なインドール前 駆体を良好な収率で与えた（Table 1).

次に，置換基の導入法について検討を行つた。前 述したインドール骨格形成反応によって生じた 2スタニルインドールへの置換基導入は，主に $\mathrm{sp}^{2}$ 八 ライド又はトリフラートとの Pd 触媒を用いたカッ プリング反応に限られていた。一般に, $\mathrm{sp}^{2}$ 炭素一 スズ結合はヨウ素により $\mathrm{sp}^{2}$ 炭素-ヨウ素結合に変 換される。そこで，1 より得られる 2-スタニル体 3

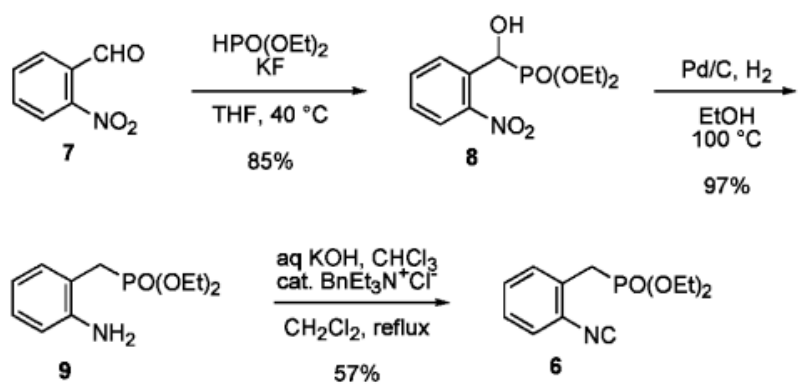

Scheme 2. Synthesis of the Horner-Emmons Reagent (6)

Table 1. Horner-Emmons Condensation with 6

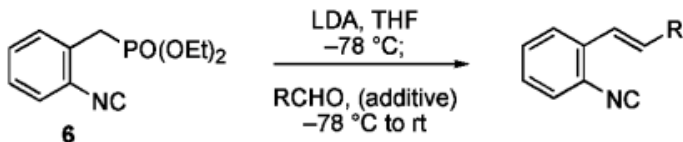

\begin{tabular}{|c|c|c|c|}
\hline Entry & $\mathrm{RCHO}$ & Additive & Yield $(\%)^{a)}$ \\
\hline 1 & & 一 & 87 \\
\hline 2 & & - & 93 \\
\hline 3 & & - & 90 \\
\hline 4 & & - & $41^{b)}$ \\
\hline 5 & & $\begin{array}{l}\text { HMPA } \\
(5 \text { eq) }\end{array}$ & $80^{c)}$ \\
\hline 6 & & $\begin{array}{l}\text { HMPA } \\
(5 \text { eq) }\end{array}$ & 78 \\
\hline
\end{tabular}

a) Only $E$ isomer was obtained unless otherwise noted. $b$ ) $E / Z$ ratio was $11 / 1$. c) $E / Z$ ratio was $3.7 / 1$. 
をヨウ素で処理したところ，2- ヨード体 $\mathbf{1 0}$ が高収 率で得られた（Scheme 3)。2- ヨード体 $\mathbf{1 0}$ は，様 々な基質とのカップリング反応に用いることがで き，薗頭反応，Heck 反応， Stille カップリング，鈴 木カップリング，一酸化炭素によるホルミル化など による 2 位置換基の導入が可能になった（Scheme 4). ${ }^{8)}$

1-2. アスピドファイチンの不斉全合成 この ように，比較的穏和で官能基の共存性の高いラジカ ル環化反応と Pd 触媒を用いたカップリング反応を 組み合わせることによって，様々な置換基を有する 2,3-二置換インドール誘導体を簡便に合成できるよ うになった。そこで，次に本反応を鍵工程に用いて 達成したアスピドファイチン (12) の不斉全合成につ いて述べる. ${ }^{9)}$

ハプロファイチン $(\mathbf{1 1})$ は, 中南米に産する Haplophyton cimicidium の葉から単離された二核性アル カロイドである。その酸性分解により得られるアス ピドファイチン $(\mathbf{1 2})$ は，アスピドスペルマ骨格を有 する 6 環性のアルカロイドである。これら化合物は, 1950 年代に Snyder らによって単離され, ${ }^{10)} 1973$ 年

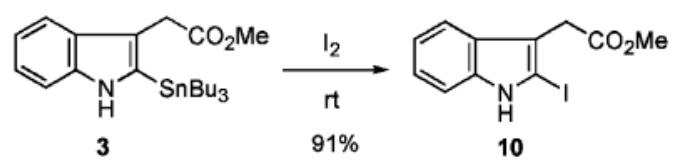

Scheme 3. Synthesis of 2-Iodoindole Derivative

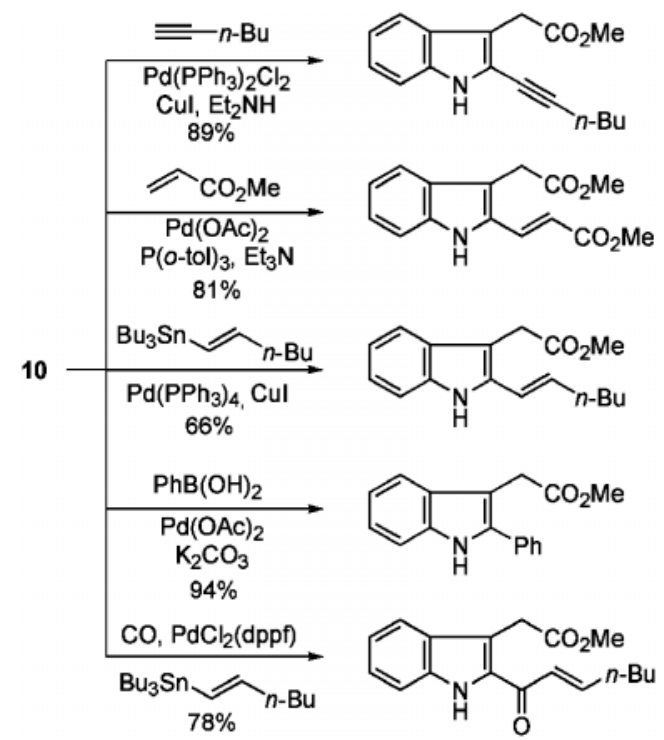

Scheme 4. Coupling Reactions to Install 2-Substituents
にCava らによって構造決定がなされた. ${ }^{11)}$ その複 雑な構造ゆえに，アスピドファイチン $(\mathbf{1 2})$ の合成に ついては, 1999 年の Corey らによる報告が唯一の 例であり, 12) ハプロファイチン (11) は未だ全合成の 報告はない。我々は最近上記インドール合成法を鍵 とする収束性の高いアスピドファイチン (12)の全合 成を達成した. ${ }^{9}$
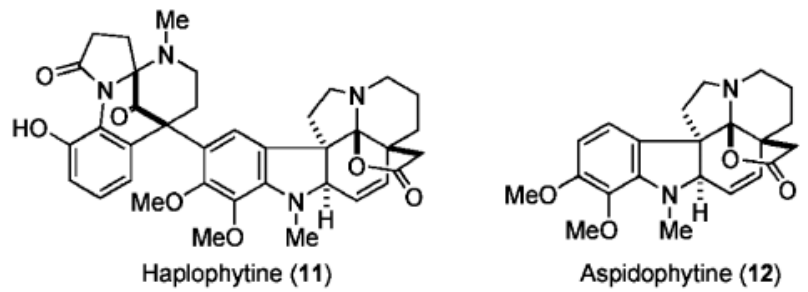

Scheme 5 にその逆合成解析を示した。 ラクトン 環は合成の終盤にて形成するものとし，また，5環 性骨格 A は 2 級アミンとアルデヒドにより生成さ せたイミニウム塩に対する分子内マンニッヒ型の反 応により立体選択的に構築できるのではないかと考 えた。また，11 員環 2 級アミン $\mathbf{B}$ は，ニトロベン ゼンスルホニル（以下 $\mathrm{Ns}$ ）基を用いた 2 級アミン の合成法 ${ }^{13)}$ によって構築することとした。また，シ スオレフィンを有する 2,3 -二置換インドールは, 先に述べたイソニトリルからのインドール合成法を 用いて, 末端アセチレン部分との薗頭カップリング による光学活性な側鎖ユニット $\mathbf{E}$ の導入と, アセ チレンの部分還元によって迅速にできるのではない かと考えた。

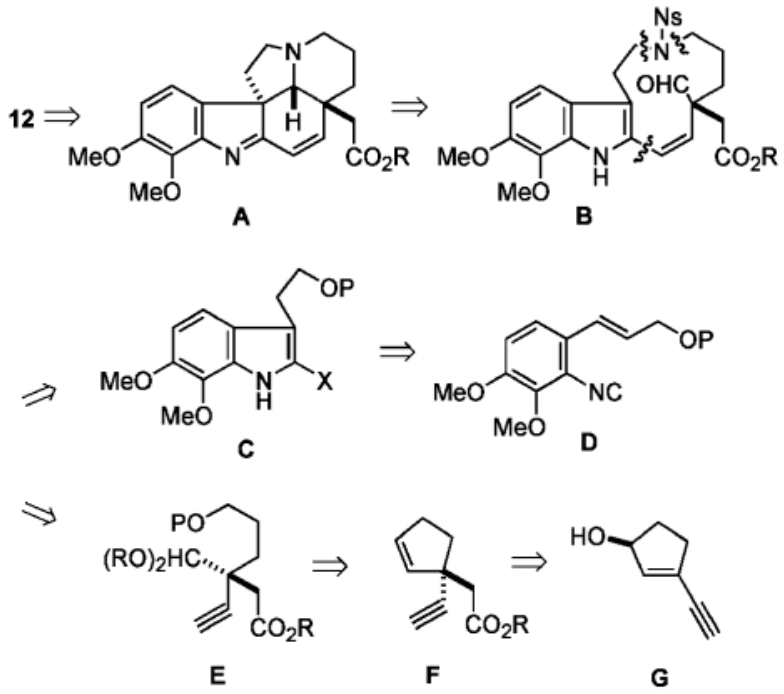

Scheme 5. Retrosynthetic Analysis of Aspidophytine 
まず，光学活性アセチレンユニットの合成を行つ た (Scheme 6)。 シクロペンテノン 13 に対するリ チウムアセチリドの付加を経て容易に得られる 14 を Amano lipase PS を用いた光学分割条件に付 し， $(S)$ - シクロペンテノール 15 を収率 $48 \%$, 光学 純度 99\% ee で得た。15 の Claisen-Johnson 転位反 応により 4 級炭素を構築し, TIPS 基を除去してシ クロペンテン 16 を得た．続いて 16 の二重結合のジ ヒドロキシル化と酸化的切断, 得られたジアルデヒ ドの還元によりジオール 17 とした。ささに，ジ オールの位置選択的な TBDPS 基での保護と, 残つ た水酸基の Swern 酸化に続くアセタール化によつ てアセチレンユニット 18 を合成した.

インドール前駆体の合成は，バニリンから数段階 の変換によって得られる 2- ニトロベラトルアルデ ヒド 19 を Horner-Emmons 反応により増炭し, 常 法によってニトロ基をイソニトリル $\mathbf{2 1}$ へ変換し 合成した (Scheme 7)。続いて，21 のラジカル環化 反応によりインドール骨格を構築し， 2 位スタニル 基のヨウ素への置換と, エステルの還元と保護を行 いインドールユニット 23 とした。

以上のようにして合成したインドールユニット 18 とアセチレンユニット $\mathbf{2 3}$ を, 薗頭反応によって 結合しアセチレン 24 を得た。 (Scheme 8）24 のイ ンドール窒素を Boc 基で保護したのちに, $\mathrm{Pd} / \mathrm{C}$ 存 在下接触還元を行ったところ, 目的とするシスオレ フィン 25 のみが良好な収率で得られた。25 のアセ
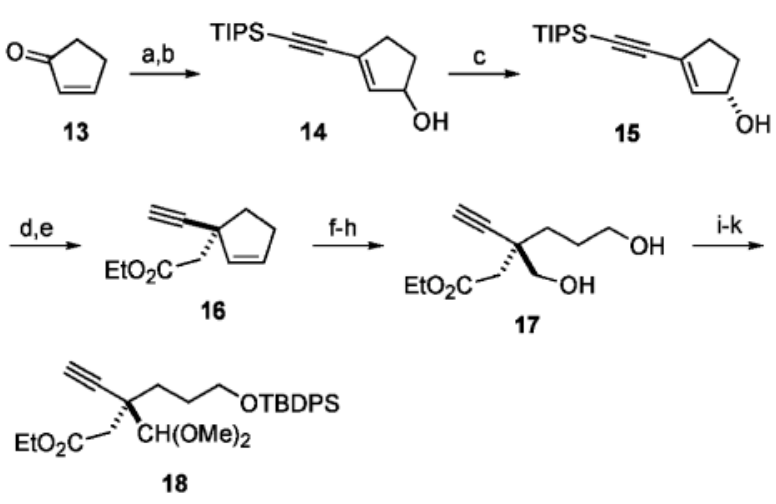

Scheme 6

a) triisopropylsilylacetylene, $n$ - BuLi, $\mathrm{CeCl}_{3}, \mathrm{THF},-78^{\circ} \mathrm{C}$, b) $3 \%$ $\mathrm{H}_{2} \mathrm{SO}_{4}, \mathrm{THF}, 94 \%$ (2 steps), c) vinyl acetate, Lipase PS, $t$-BuOMe, $45-50$ ${ }^{\circ} \mathrm{C}, 48 \%\left(99 \%\right.$ ee) , d) $\mathrm{CH}_{3} \mathrm{C}(\mathrm{OEt})_{3}, t-\mathrm{BuCO}_{2} \mathrm{H}$, xylene, reflux, e) TBAF, $\mathrm{THF}, 50^{\circ} \mathrm{C}$, f) $\mathrm{OsO}_{4}$, NMO, acetone $-\mathrm{H}_{2} \mathrm{O}, 0^{\circ} \mathrm{C}$ to rt, g) $\mathrm{NaIO}_{4}$, THF- $\mathrm{H}_{2} \mathrm{O}, 0$ ${ }^{\circ} \mathrm{C}, \mathrm{h}$ ) $\mathrm{NaBH}_{4}, \mathrm{EtOH},-20^{\circ} \mathrm{C}, 38 \%$ (5 steps), i) TBDPSCl, DMAP, $\mathrm{Et}_{3} \mathrm{~N}$, $\mathrm{CH}_{2} \mathrm{Cl}_{2},-20$ to $\left.-10^{\circ} \mathrm{C}, 95 \%, \mathrm{j}\right)(\mathrm{COCl})_{2}$, DMSO, $\mathrm{CH}_{2} \mathrm{Cl}_{2},-78^{\circ} \mathrm{C} ; \mathrm{Et}_{3} \mathrm{~N}$, k) $\mathrm{CSA}, \mathrm{HC}(\mathrm{OMe})_{3}, \mathrm{MeOH}, 74 \%$ (2 steps).
チル基を除去し，光延反応によりアミノ基を導入し 化合物 26 とした。次に TBDPS 基を除去し，分子 内光延反応を行うことにより 11 員環化合物 27 を良 好な収率にて得ることができた。続いて，TMSBr を用いてアセタールを脱保護し，さらに Ns 基を $\mathrm{Cs}_{2} \mathrm{CO}_{3}$ 存在下 $\mathrm{PhSH}$ により除去した。 TFA で処理 したのち， buffer 中（pH 7.8）で攪汼することによ り Boc 基の脱保護と続く環化反応が進行し 5 環性 化合物 $\mathbf{2 8}$ が得られた。 イミン部分の還元と, アミ ノ基の還元的メチル化を同時に行い，最終中間体 29 を経てエステルの加水分解と酸化的ラクトン化 によってアスピドファイチン (12) の不斉全合成を完 了した，以上のように，ラジカル環化反応と $\mathrm{Pd}$ 触 媒を用いた穏和な反応を用いることで，収束性の高 い効率的なアスピドファイチン $(\mathbf{1 2})$ の合成経路を確 立することができた．現在，ハプロファイチン $(\mathbf{1 1})$ の合成に向けてさらなる検討を行っている.

1-3. 第二世代インドール合成法の開発先に 述ベたイソニトリルを用いたインドール合成法は, ラジカル環化後に Pd 触媒を用いたカップリング反 応によって様々な置換基を導入できる点に特徴があ る.しかしながら，Pd 触媒を用いているために， $\mathrm{sp}$ 又は $\mathrm{sp}^{2}$ 炭素の導入には有効であるのに対して, $\mathrm{sp}^{3}$ 炭素の導入は困難である。 そこで, Scheme 9 に 示した作業仮説を基に新たな反応開発の検討を行っ た. ${ }^{14)}$ すなわち, 先の反応でイソニトリルのかわり にチオアミドを有する基質 $(\mathbf{3 0})$ を用いれば，スズラ ジカルがイオウ原子に付加して生じた $\mathrm{sp}^{3}$ ラジカル がオレフィンに対して環化し，生じたラジカルが還 元されたのちに芳香環化してインドール骨格を与え
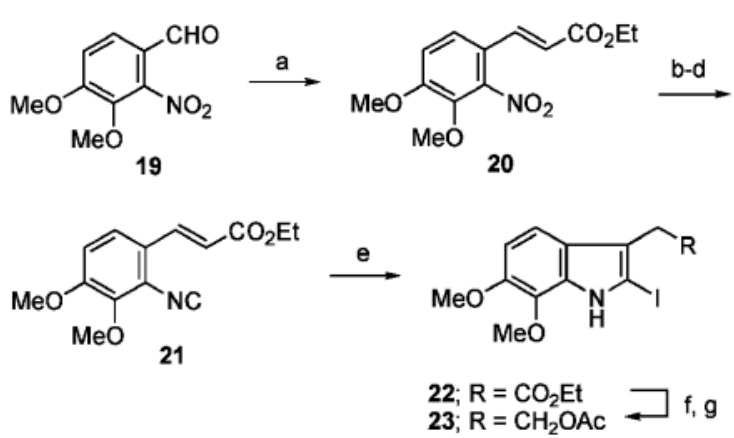

Scheme 7.

a) (EtO) ${ }_{2} \mathrm{POCH}_{2} \mathrm{CO}_{2} \mathrm{Et}, n-\mathrm{Bu}_{4} \mathrm{NI}, \mathrm{CH}_{2} \mathrm{Cl}_{2}$, aq $\mathrm{NaOH}, 5^{\circ} \mathrm{C}, 81 \%$, b) $\mathrm{Zn}, \mathrm{AcOH}, \mathrm{CH}_{2} \mathrm{Cl}_{2}, 5^{\circ} \mathrm{C}$ to rt, c) $\mathrm{HCO}_{2} \mathrm{H}, \mathrm{Ac}_{2} \mathrm{O}, 5^{\circ} \mathrm{C}$, d) $\mathrm{POCl}_{3}, \mathrm{Py}$, $\mathrm{CH}_{2} \mathrm{Cl}_{2}, 5^{\circ} \mathrm{C}, 63 \%$ (3 steps), e) $n$ - $\mathrm{Bu}_{3} \mathrm{SnH}, \mathrm{AIBN}, \mathrm{MeCN}$, reflux; $\mathrm{I}_{2}, 85 \%$, f) DIBAL, toluene, $10^{\circ} \mathrm{C}, \mathrm{g}$ ) $\mathrm{Ac}_{2} \mathrm{O}, \mathrm{Py}, 85 \%$ (2 steps). 


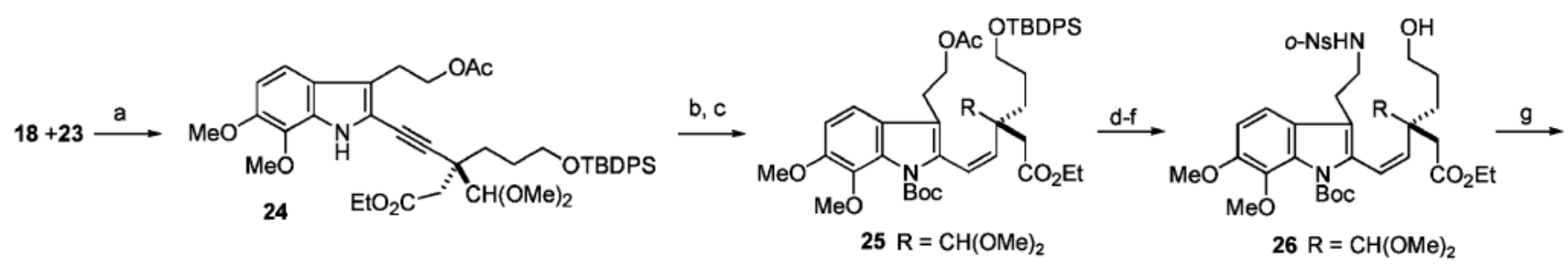

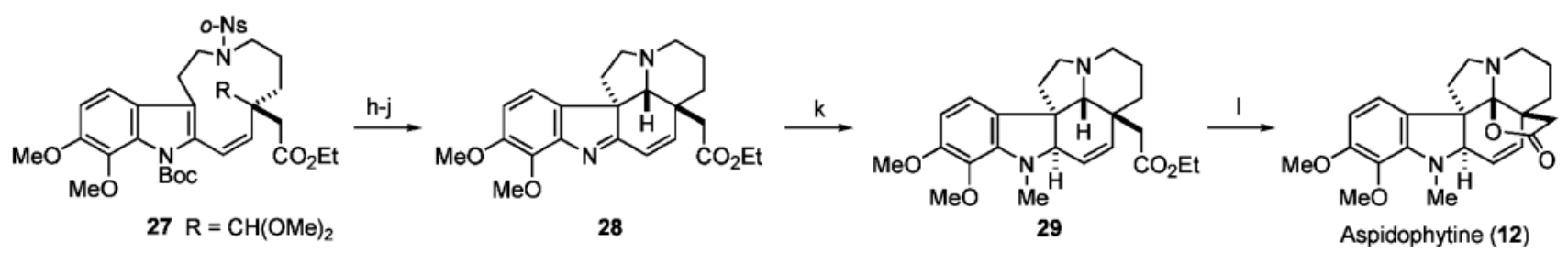

Scheme 8 .

a) $\mathrm{Pd}\left(\mathrm{PPh}_{3}\right)_{4}, \mathrm{CuI}, \mathrm{Et}_{3} \mathrm{~N}, 70^{\circ} \mathrm{C}, 78 \%$, b) $\mathrm{Boc}_{2} \mathrm{O}$, DMAP, $\mathrm{MeCN}, 94 \%$, c) $\mathrm{Pd} / \mathrm{C}_{1} \mathrm{H}_{2}, \mathrm{EtOH}, 97 \%$, d) $\mathrm{K}_{2} \mathrm{CO}_{3}, \mathrm{MeOH}, 96 \%$, e) $\mathrm{NsNH}$, $\mathrm{PPh}$, DEAD, $\mathrm{PhH}, 93$

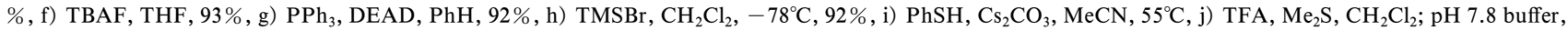
$56 \%$ (2 steps), k) $\mathrm{HCHO}, \mathrm{NaBH}_{3} \mathrm{CN}, \mathrm{pH} 7.0$ buffer, $-70^{\circ} \mathrm{C}$ to rt, $\left.67 \%, 1\right) \mathrm{NaOH}, \mathrm{EtOH}, 70^{\circ} \mathrm{C} ; \mathrm{K}_{3} \mathrm{Fe}(\mathrm{CN})_{6}, \mathrm{NaHCO}_{3}, 5^{\circ} \mathrm{C}$ to rt, $39 \%(2$ steps $)$.

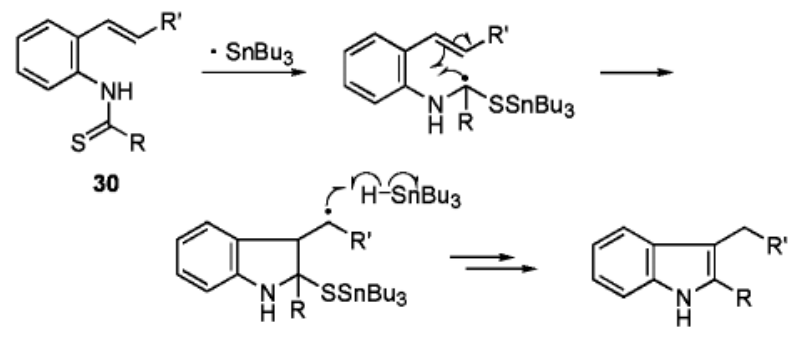

Scheme 9. Working Hypothesis for New Indole Synthesis

るのではないかと考えた.

まず，モデル基質 $(\mathbf{3 1})$ を合成し反応を試みたとこ ろ, 反応開始剤として AIBN を用いた加熱条件 下，又は $\mathrm{Et}_{3} \mathrm{~B}$ を用いた室温下での反応のいずれも

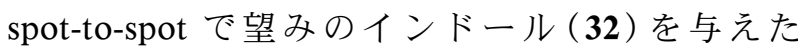
(Scheme 10)。また興味深いことに，トランス体よ りもシス体の基質が反応速度及び収率ともに上回る ことが分かった。

反応条件としては，ヒドリド源として通常用いら れているスズヒドリドのかわりに，毒性が低く除去 が容易な次亜リン酸を用いても望みの反応が進行す ることが分かった. Scheme 11 に示すように，この 条件は立体的にかさ高い置換基の導入に特に有効で あり，本条件によりチオアミド $(\mathbf{3 3})$ から 1-アダマ ンチル基を有するインドール誘導体 (34) が良好な収 率で得られた. ${ }^{15)}$

次に, インドール前駆体であるチオアミドの簡便 かつ一般性の高い合成手法の確立を図ることとし た. その結果, Scheme 12 に示す主に2つの経路で

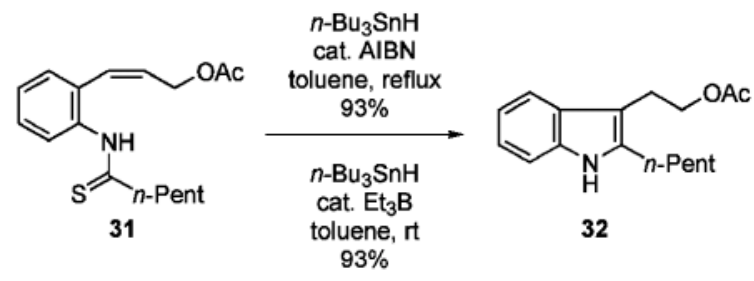

Scheme 10. Model Reaction

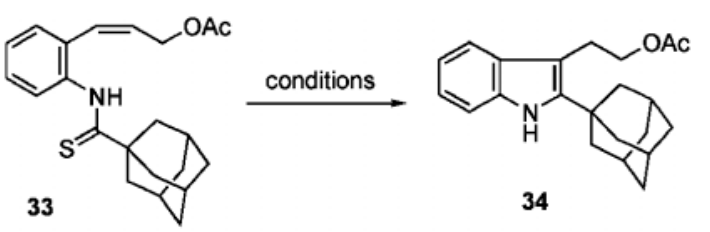

$n-\mathrm{Bu}_{3} \mathrm{SnH}(1.5 \mathrm{eq}), \mathrm{Et}_{3} \mathrm{~B}(0.1 \mathrm{eq}) \quad 35 \%$ toluene, rt, $2 \mathrm{~h}$

$\mathrm{H}_{3} \mathrm{PO}_{2}$ (10 eq), AIBN (1.2 eq) $\mathrm{Et}_{3} \mathrm{~N}(15 \mathrm{eq}), n-\mathrm{PrOH}_{\text {, reflux, } 30 \mathrm{~min}} 75 \%$

Scheme 11. Tin-free Reaction Conditions

の合成法を確立することができた. ${ }^{14)}$

1 つ目は，キノリン $(\mathbf{3 5})$ の開環反応により得られ るイソチオシアネート $(\mathbf{3 6})$ に対する求核剤の付加反 応によりチオアミド $(37)$ を直接得る方法である. ま た，36 から塩基性条件下得られるアニリン $(38)$ と カルボン酸からアミドとし, ローソン試薬でチオア ミド (37) を得ることも可能である. もう一方の方法 は, オルトヨードアニリン (39) と末端アセチレンと の薗頭カップリングののちに, オレフィンへの部分 還元を経て，アミドからチオアミド $(\mathbf{4 1})$ へと変換す 


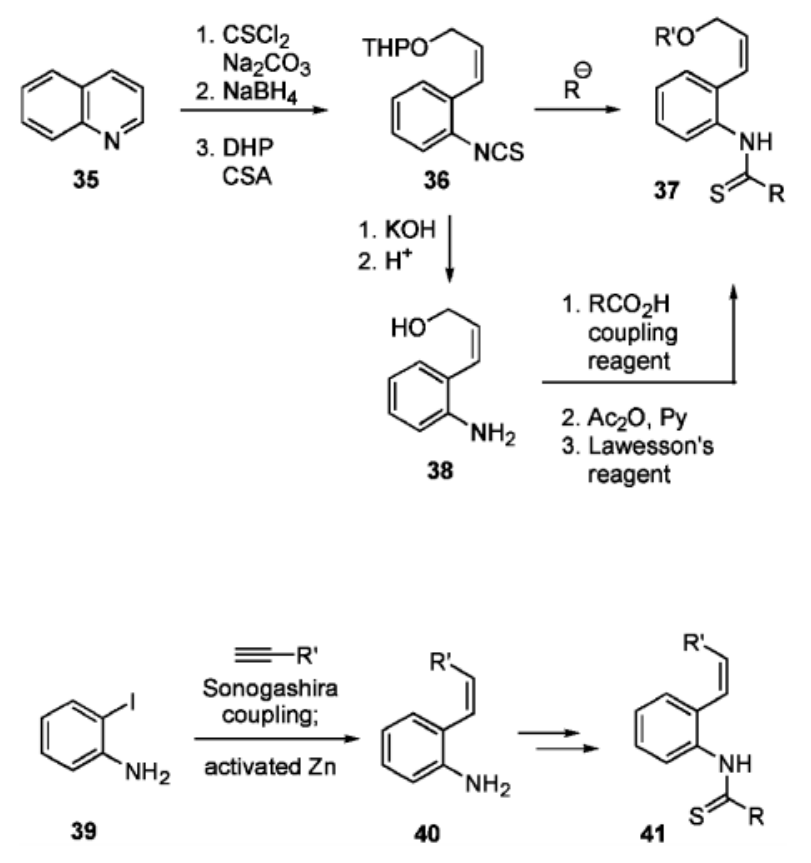

Scheme 12. General Scheme for the Preparation of Thioanilides

る方法である.

上記の合成手法の特徵は，インドール 2 位の置換 基をカルボン酸又はエステルエノラートなどの求核 剂として別途準備したうえで導入可能な点である.

一方， 3 位置換基についても末端アセチレンとして 比較的自由にインドール前駆体に組み込める。 ま た, 反応は中性条件下進行するために, 塩基性及び 酸性に不安定な官能基が共存できる。ささらに，キノ リンを出発原料として用いるとインドール形成後 3 位にヒドロキシエチル基を導入できるので, 天然に 多く見られるトリプタミンユニットを有する化合物 の合成に特に有用である。このように, 本手法は複 雑な多官能基性インドールの収束的な合成に適して いると考えられる.

1-4. カタランチンの全合成上記の特徵を最 大限に活用した収束性の高い合成戦略によって, 个 ンドールアルカロイドカタランチン (42)の全合成を 達成したので紹介したい. ${ }^{15,16)}$

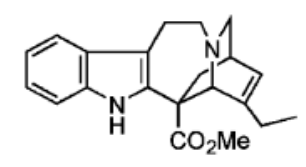

Catharanthine (42)
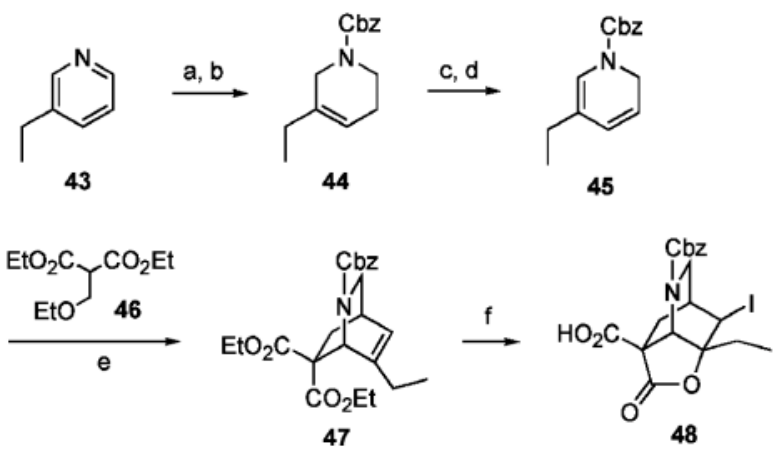

Scheme 13.

a) i) $\mathrm{BnBr}, 0^{\circ} \mathrm{C}$ to rt, ii) $\mathrm{NaBH}_{4}, \mathrm{EtOH}, 0^{\circ} \mathrm{C}$, b) $\mathrm{CbzCl}, \mathrm{PhH}, 80^{\circ} \mathrm{C}, 62$ \% (3 steps), c) $\mathrm{Br}_{2}, \mathrm{CH}_{2} \mathrm{Cl}_{2}$, rt, $97 \%$, d) $\mathrm{DABCO}, \mathrm{MeCN}, 80^{\circ} \mathrm{C}$, e) $100^{\circ} \mathrm{C}$, f) i) $\mathrm{KOH}, \mathrm{EtOH}, \mathrm{H}_{2} \mathrm{O}, 80^{\circ} \mathrm{C}$, ii) $\mathrm{I}_{2}, \mathrm{NaHCO}_{3}, \mathrm{H}_{2} \mathrm{O}, 67 \%$ (4 steps).

まず，インドール 2 位に導入するカルボン酸部ユ

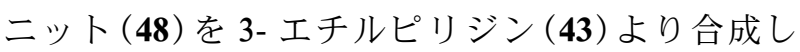
た。常法によりデヒドロピリジン誘導体 (45) に導 き, ジエチルエトキシメチルマロネート(46) から生 成させたジエチルエチリデンマロネートとの DielsAlder 反応によってイソキヌクリジン骨格 (47) を構 築した. 最後にヨードラクトン化によって 2 つのエ ステルを区別し, カルボン酸ユニット $(\mathbf{4 8})$ を得た (Scheme 13).

そして次に, キノリンより導いたアニリン $(\mathbf{3 8})$ と 縮合し, 数段階の変換でインドール前駆体であるチ オアミド $(\mathbf{5 0})$ へ変換した. ここで，スズヒドリド を用いた条件を種々検討したが，望みのインドール 環化体は低収率でしか得られなかった。最終的に は，スズヒドリドを用いない，すなわち，次亜リン 酸とAIBN を用いた加熱条件下, かさ高い 4 級炭 素中心を 2 位に有するインドール骨格 $(\mathbf{5 1})$ を良好な 収率で構築することに成功した（Scheme 14）。

以上のように，インドールを含む比較的複雑な骨 格をキノリンとカルボン酸部位から収束的かつ迅速 に構築することに成功した。 また，今回紹介した 2 つのインドール合成法は，2 位の置換基の導入に関 して互いに相補的な関係にあり, 両者を使い分ける ことで, 幅広いインドール誘導体が合成可能である.

1-5. ビンブラスチンの立体選択的不斉全合成 さらに, 本合成法を基盤として, ビンカアルカロイ ドの代表的化合物であるビンブラスチン $(\mathbf{5 2})$ の全合 成を達成することができた. ${ }^{17)}$ ビンブラスチン (52) は Catharanthus roseus から見い出されたアルカロ イドであり, 現在, 悪性リンパ腫, 絨毛性腫瘍の有 

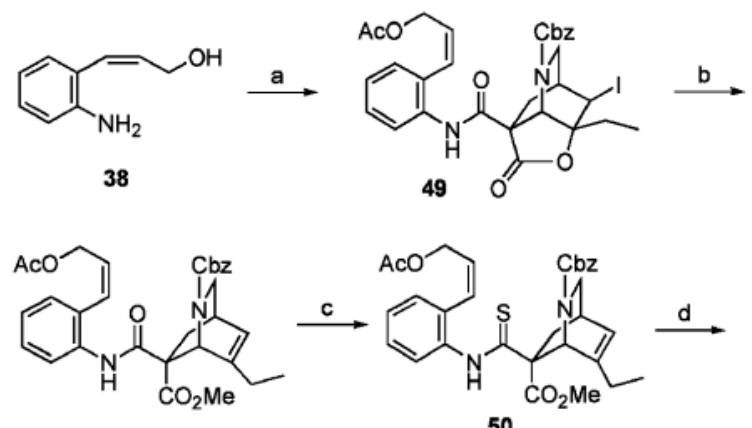

50

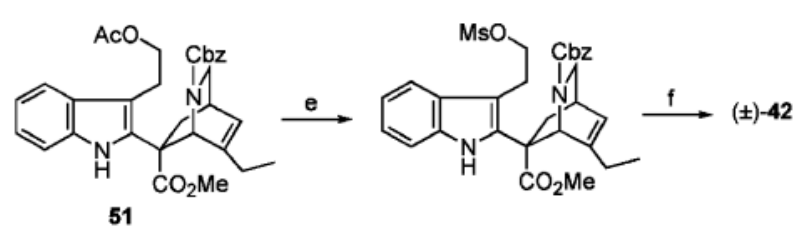

Scheme 14.

a) i) 48, WSCD, $\mathrm{Et}_{3} \mathrm{~N}, \mathrm{CH}_{2} \mathrm{Cl}_{2}$, ii) $\mathrm{Ac}_{2} \mathrm{O}, \mathrm{Py}, 74 \%$, b) i) $\mathrm{Zn}, \mathrm{AcOH}$, $\mathrm{CH}_{2} \mathrm{Cl}_{2}$, ii) $\mathrm{CH}_{2} \mathrm{~N}_{2}, \mathrm{Et}_{2} \mathrm{O}, 83 \%$ (2 steps), c) Lawesson's reagent, $\mathrm{Py}, \mathrm{PhMe}$, $110^{\circ} \mathrm{C}, 86 \%$, d) AIBN, $\mathrm{H}_{3} \mathrm{PO}_{2}, \mathrm{Et}_{3} \mathrm{~N}, n-\mathrm{PrOH}, 90^{\circ} \mathrm{C}, 40-50 \%$, e) i) $\mathrm{K}_{2} \mathrm{CO}_{3}$, $\mathrm{MeOH}$, ii) $\mathrm{MsCl}, \mathrm{Et}_{3} \mathrm{~N}, \mathrm{CH}_{2} \mathrm{Cl}_{2}, 82 \%$ (2 steps), f) $\mathrm{Et}_{3} \mathrm{SiH}, \mathrm{Pd}(\mathrm{OAc})_{2}$, $\mathrm{Et}_{3} \mathrm{~N}, \mathrm{EtOH}, \mathrm{EtOAc}, 96 \%$.

効な治療薬として使用されている. ${ }^{18)}$ また, 構造的 には上部カルボメトキシベルバナミン部位と下部ビ ンドリン部位の 2 種類の異なるインドールユニット が結合した特異な構造を有していることから, 合成 化学的にも興味を集めこれまで多くの合成研究が行

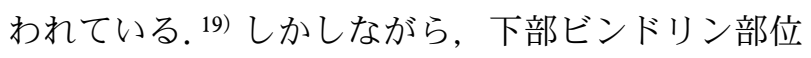
でさえも効率的な合成法がなく, ビンブラスチン合 成研究への化合物供給と言う意味では不十分であっ た.したがって, 数例達成されているビンブラスチ ンの合成は, いずれも天然物であるビンドリンを原 料として用いている. ${ }^{20-23)}$ 現在でもビンブラスチ ンをリード化合物とした新規医薬品の創製が望まれ ており，系統的な誘導体合成を可能にするための効 率的なビンブラスチンの合成手法の確立は必須の課 題である.

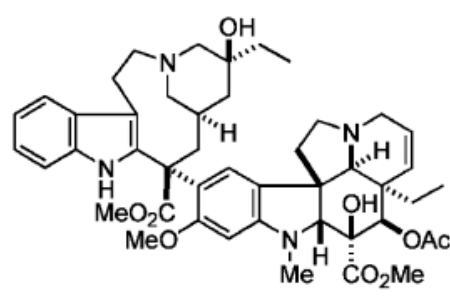

(+)-Vinblastine (52)

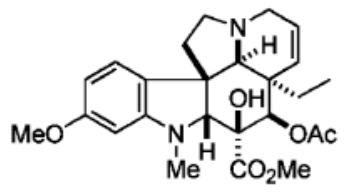

(-)-Vindoline(53)
ビンブラスチンの下部を構成する（一）-ビンド リン $(\mathbf{5 3})$ は, 当研究室において既にその全合成を達 成している. ${ }^{4)} し$ しビンブラスチンの合成研究に<smiles>CCOc1ccc(OC)cc1N(C)C</smiles>

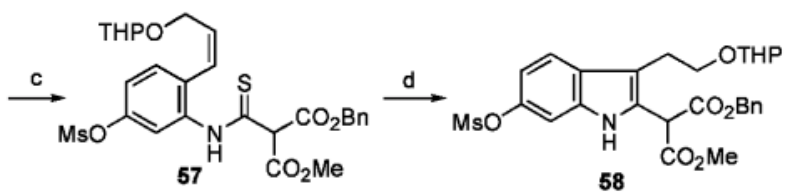

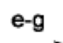<smiles>C=C(C(=O)OC)n1c(C(=O)OC)c(CCO)c2ccc(OC)cc21</smiles>

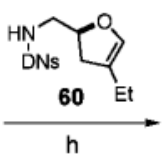

59

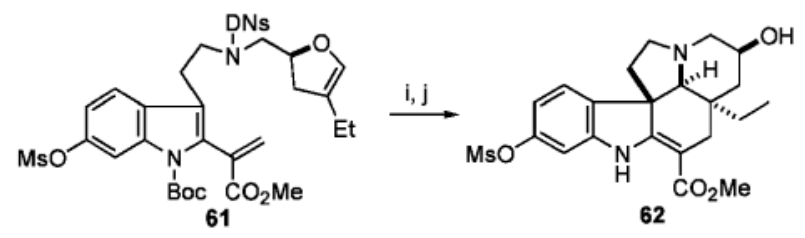

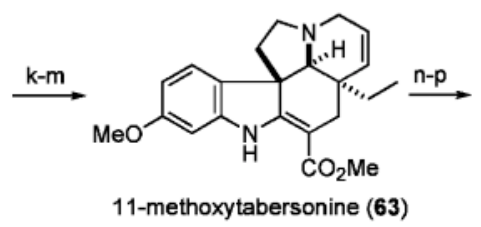

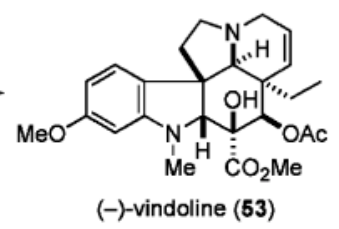

Scheme 15

a) thiophosgene, $\mathrm{Na}_{2} \mathrm{CO}_{3}$, THF- $\mathrm{H}_{2} \mathrm{O}, 0^{\circ} \mathrm{C} ; \mathrm{NaBH}_{4}, 0^{\circ} \mathrm{C}, 72 \%$ (2 steps), b) DHP, cat. CSA, $\mathrm{CH}_{2} \mathrm{Cl}_{2}$, quant., c) benzyl methyl malonate, $\mathrm{NaH}$, THF, $0^{\circ} \mathrm{C}, 96 \%$, d) $\mathrm{AIBN}, \mathrm{Bu}_{3} \mathrm{SnH}, \mathrm{PhMe}, 110^{\circ} \mathrm{C}, 97 \%$, e) $\mathrm{Boc}_{2} \mathrm{O}, \mathrm{Et}_{3} \mathrm{~N}, \mathrm{DMAP}$, $\mathrm{CH}_{2} \mathrm{Cl}_{2}, \mathrm{rt}, 98 \%$, f) $\mathrm{H}_{2}, \mathrm{Pd} / \mathrm{C}, \mathrm{EtOH} ; \mathrm{Me}_{2} \mathrm{NH} \cdot \mathrm{HCl}, \mathrm{HCHO}, \mathrm{AcONa}$, $\mathrm{AcOH}-\mathrm{EtOH}, 77 \%$ (2 steps), g) CSA, $\mathrm{MeOH}, 99 \%$, h) DEAD, $\mathrm{Ph}_{3} \mathrm{P}, \mathrm{PhH}$, $79 \%$, i) TFA, $\left.\mathrm{Me}_{2} \mathrm{~S}, \mathrm{CH}_{2} \mathrm{Cl}_{2}, 0^{\circ} \mathrm{C}, \mathrm{j}\right)$ pyrrolidine, $\mathrm{MeOH}-\mathrm{CH}_{3} \mathrm{CN}$, rt to $60^{\circ} \mathrm{C}$, $73 \%$ (2 steps), k) $\left.\mathrm{Ph}_{3} \mathrm{P}, \mathrm{CCl}_{4}, \mathrm{CH}_{3} \mathrm{CN}, 70^{\circ} \mathrm{C}, 85 \%, 1\right) \mathrm{KOH}, \mathrm{MeOH}, 80^{\circ} \mathrm{C}$, m) $t$-BuOK, MeI, THF, $77 \%$ (2 steps), n) $(\mathrm{PhSeO})_{2} \mathrm{O}, \mathrm{PhH}, 80^{\circ} \mathrm{C} ; \mathrm{H}_{2} \mathrm{O}, 80$ ${ }^{\circ} \mathrm{C}, 88 \%$, o) $m \mathrm{CPBA}, \mathrm{MeOH}-\mathrm{CH}_{2} \mathrm{Cl}_{2}$, sat $\mathrm{NaHCO}_{3}$; $\mathrm{NaBH}_{3} \mathrm{CN}, \mathrm{pH} 3$; $\mathrm{HCHO}, \mathrm{NaBH}_{3} \mathrm{CN}, 64 \%$ (3 steps), p) $\mathrm{Ac}_{2} \mathrm{O}, \mathrm{AcONa}, 91 \%$.

は十分ではなく，上記新規インドール合成法を用い たより効率的な合成法の開発を行った.

7-メシルオキシキノリン $(\mathbf{5 5})$ を，独自のキノリ ン合成法を用いて 3- ヒドロキシアニリン $(\mathbf{5 4}) よ り$ 合成した (Scheme 15). ${ }^{24)}$ チオホスゲンによるキノ リン $(\mathbf{5 5})$ の開環, アルデヒドの還元と生じた水酸基 の保護により得られるイソチオシアネート $(\mathbf{5 6})$ に対 し, マロン酸ジエステルを付加しチオアニリド (57) を得た. インドール形成反応に続く数工程の変換に よりアクリル酸誘導体 $(\mathbf{5 9})$ へと変換した. 次に, 59 と, 酵素による光学分割を用いて合成した光学活性 2,4- ジニトロベンゼンスルホンアミド (DNs アミ ド） 60 とを光延反応により縮合した。得られた 61 をトリフルオロ酢酸で処理しBoc 基の除去とエ 
ノールエーテルの水和を行ったのち，ピロリジンに よる DNs 基を除去と加熱により 5 環性化合物 (62) が得られた。 その後, 数段階を経て 11-メトキシ夕 ベルソニン $(63)$ へと導き，既存の手法の改良法を用 いてビンドリン $(\mathbf{5 3})$ を合成した.

上部インドールユニットとビンドリンとのカップ リング反応においては，2つのインドールユニット の結合の立体化学の制御が重要な問題となる。例え ば上部ユニット 64 に対して直接ビンドリンを導入 すると，天然体のエピマーを与えることが報告され ている. ${ }^{23)}$ 我々は, Schill らのモデル化合物 65 を用 いると天然体の立体化学を有する化合物が得られる との報告25)を基に，66 のような 11 員環化合物とビ ンドリンとのカップリング反応を試みることとした。

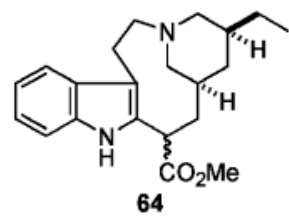<smiles>COC[C@H](CCN(C)C)C[C@H](COC)c1[nH]c2ccccc2c1CN(C)C(C)(C)C</smiles>

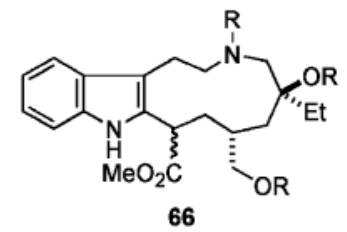

66 の合成は，チオアニリドからのインドール合 成法を用いることとし，まず，インドール前駆体合 成に必要なエステルユニット $(67)$ の合成を行った (Scheme 16).

$n$-ブチルアルデヒドから 2 工程で得られるアル コール $(68)$ を, Claisen-Johnson 反応により増炭 し, 得られたエステルの加水分解後カルボン酸 69 を得た。 69 に対しオキサゾリジノン型不斉補助基 を導入し，得られたイミド 70 を Evans らの Michael 反応の条件に付したところ, 反応は高ジア ステレオ選択的に進行し 71 を与えた。不斉補助基 の還元的除去と生じた水酸基の保護ののち, 72 の ニトリルのアルデヒドへの還元を経てオキシム 73 へと変換した。 73 を次亜塩素酸ナトリウムで処理 したところ，ニトリルオキシドの生成と続く分子内 1,3- 双極子付加環化反応により，イソキサゾリン 74 が単一異性体として得られた. 74 の N-O 結合を 還元的に開裂しヒドロキシケトンとし，続いて Baeyer-Villiger 反応を行いラクトン 75 を得た。加 メタノール分解によりラクトンを開環し, 得られた

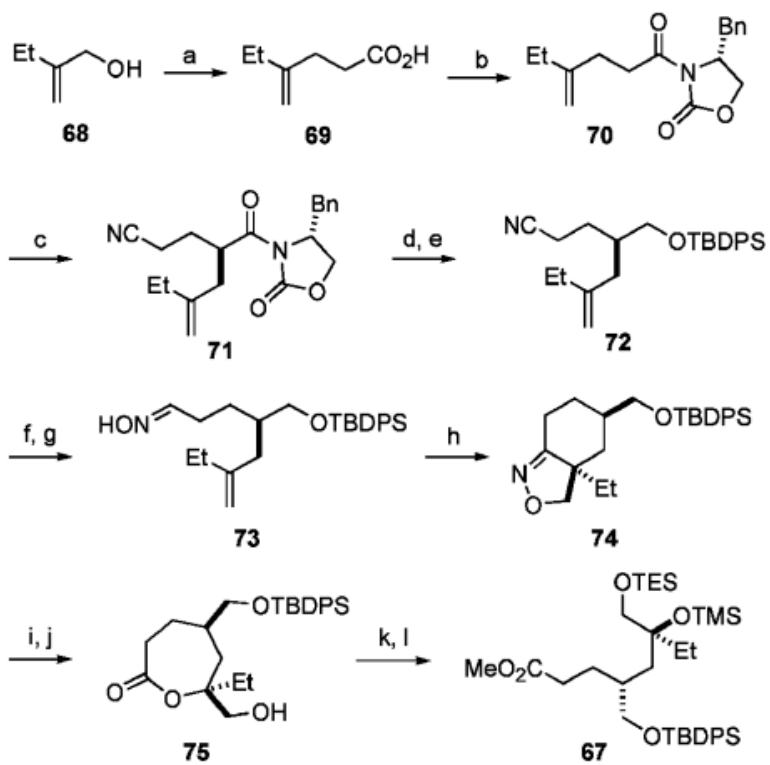

Scheme 16.

a) $\mathrm{CH}_{3} \mathrm{C}(\mathrm{OEt})_{3}, \mathrm{EtCO}_{2} \mathrm{H}, 135^{\circ} \mathrm{C}, \mathrm{KOH}, \mathrm{EtOH}-\mathrm{H}_{2} \mathrm{O}, 83 \%$, b) PivCl, $\mathrm{Et}_{3} \mathrm{~N}, \mathrm{Et}_{2} \mathrm{O}, 0^{\circ} \mathrm{C} ; n$ - $\mathrm{BuLi},(R)$-4-benzyl-2-oxazolidinone, THF, $-78^{\circ} \mathrm{C}, 89$ $\%$, c) (i-PrO) $\mathrm{TiCl}_{3}, i$ - $\mathrm{Pr}_{2} \mathrm{NEt}$, acrylonitrile, $\mathrm{CH}_{2} \mathrm{Cl}_{2}, 0^{\circ} \mathrm{C}, 82 \%$, d) $\mathrm{NaBH}_{4}$, THF- $\mathrm{H}_{2} \mathrm{O}, \mathrm{rt}, 92 \%$, e) TBDPSCl, imid., DMF, $92 \%$, f) DIBAL, $\mathrm{CH}_{2} \mathrm{Cl}_{2}$, $-78^{\circ} \mathrm{C}$, g) $\left.\mathrm{H}_{2} \mathrm{NOH} \cdot \mathrm{HCl}, \mathrm{NaOAc}, \mathrm{EtOH}, \mathrm{h}\right) \mathrm{NaClO}$ aq, $\mathrm{CH}_{2} \mathrm{Cl}_{2}, 59 \%$ (3 steps), i) $\mathrm{Zn}, \mathrm{AcOH}, 66 \%$, j) $m \mathrm{CPBA}, \mathrm{AcOH}, \mathrm{k}) \mathrm{K}_{2} \mathrm{CO}_{3}, \mathrm{MeOH}, 80 \%$ (2 steps), l) TESCl, imid., DMF; TMSCl, $92 \%$.

ジオールの 2 つの水酸基を保護することにより, 目 的とするエステル 67 を得た。

続いて，67 由来の側鎖を有するインドール骨格 と 11 員環の構築を行った (Scheme 17). 合成した エステル 67 のリチウムエノラートをイソチオシア ネート 76 に付加し，チオアニリド 77 を得た。 77 のラジカル環化反応は室温下速やかに進行してイン ドール 78 を与え，続いて保護，脱保護を行いトリ

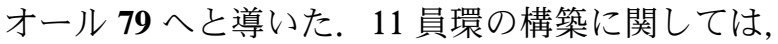
2- ニトロベンゼンスルホンアミド（Ns アミド）の アルキル化反応を用いる中大員環合成法が有効であ つた。まず 79 の 1,2- ジオールの 1 級水酸基を選択 的にトシル化し, 塩基の存在下加熱することにより エポキシド 80 へと変換した. 残った 1 級水酸基に 対し光延反応により Ns アミドを導入し，環化前駆 体 81 へと導いた. 81 を炭酸カリウム存在下加熱条 件に付したところ，エポキシドへの分子内求核攻撃 が進行し 11 員環化合物 82 が得られた。続いて, 脱 保護と保護を行いカップリング前駆体 83 へと導い た.

次に最終段階での 2 つのインドールユニットのカ ップリング反応を行った（Scheme 18)。まず, $t$ - 

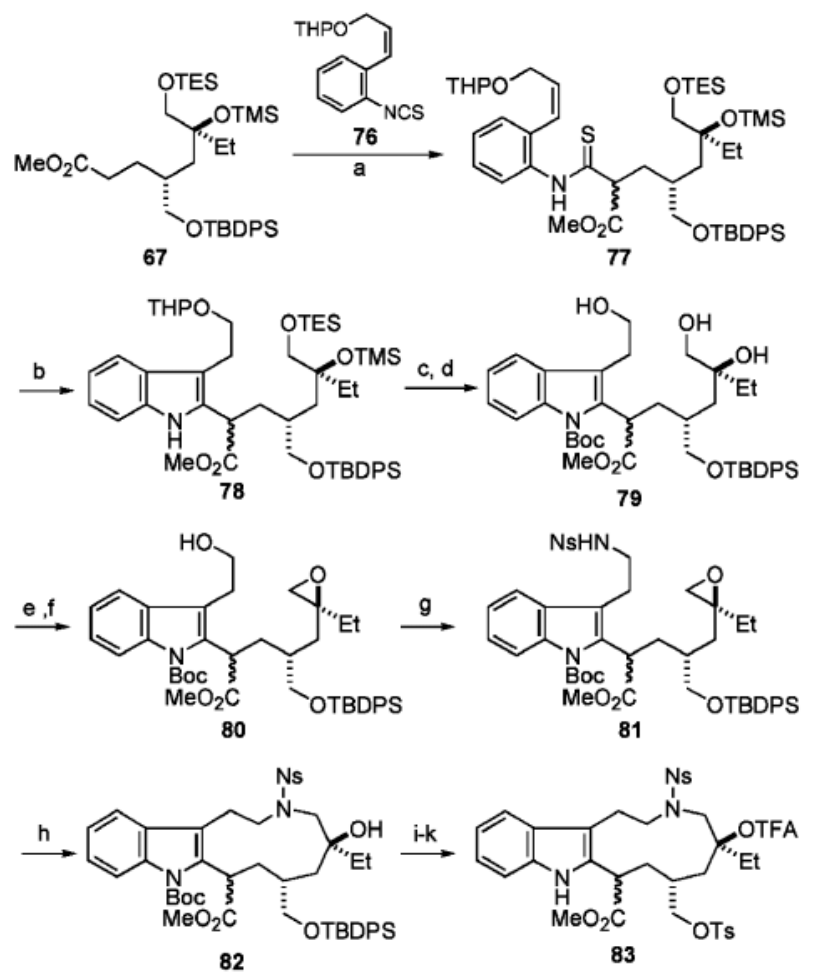

Scheme 17.

a) LDA, THF, $-78^{\circ} \mathrm{C} ; \mathbf{7 6},-78$ to $0^{\circ} \mathrm{C}, 76 \%$, b) $\mathrm{Bu}_{3} \mathrm{SnH}_{2} \mathrm{Et}_{3} \mathrm{~B}, \mathrm{THF}$, $67 \%$, c) $\mathrm{Boc}_{2} \mathrm{O}, \mathrm{Et}_{3} \mathrm{~N}$, DMAP, $\mathrm{CH}_{2} \mathrm{Cl}_{2}, 87 \%$, d) $\mathrm{AcOH}-\mathrm{H}_{2} \mathrm{O}(95: 5), 80^{\circ} \mathrm{C}$, $71 \%$, e) $\mathrm{TsCl}, \mathrm{Bu}_{2} \mathrm{SnO}, \mathrm{Et}_{3} \mathrm{~N}, \mathrm{CH}_{2} \mathrm{Cl}_{2}, 88 \%$, f) $\mathrm{NaHCO}_{3}$, DMF, $80^{\circ} \mathrm{C}, 90 \%$, g) $\mathrm{NsNH}_{2}$, DEAD, $\mathrm{Ph}_{3} \mathrm{P}, \mathrm{PhMe}, 88 \%$, h) $\mathrm{K}_{2} \mathrm{CO}_{3}$, DMF, $90^{\circ} \mathrm{C}, 82 \%$, i) TFA, $\left.\left.\mathrm{CH}_{2} \mathrm{Cl}_{2}, 85 \%, \mathrm{j}\right) \mathrm{TsCl}, \mathrm{Me}_{2} \mathrm{~N}\left(\mathrm{CH}_{2}\right)_{3} \mathrm{NMe}_{2}, \mathrm{CH}_{3} \mathrm{CN}-\mathrm{PhMe}, 88 \%, \mathrm{k}\right)$ TFAA, $\mathrm{Py}, \mathrm{CH}_{2} \mathrm{Cl}_{2}, 90 \%$.

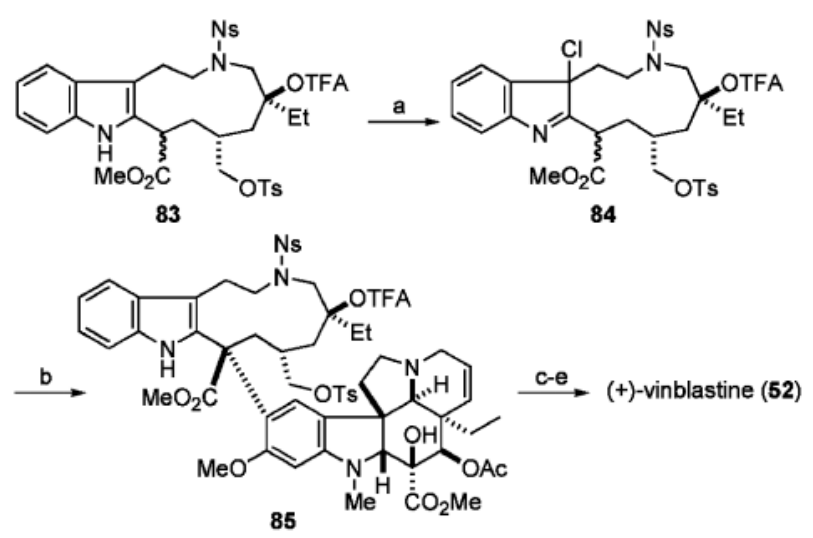

Scheme 18 .

a) $t$ - $\left.\mathrm{BuOCl}, \mathrm{CH}_{2} \mathrm{Cl}_{2}, 0^{\circ} \mathrm{C}, \mathrm{b}\right)(-)$-vindoline (53), TFA, $\mathrm{CH}_{2} \mathrm{Cl}_{2}, 0^{\circ} \mathrm{C}$ to rt, $97 \%$, c) $\mathrm{Et}_{3} \mathrm{~N}, \mathrm{MeOH}$, quant., d) $\mathrm{HSCH}_{2} \mathrm{CH}_{2} \mathrm{OH}, \mathrm{DBU}, \mathrm{CH}_{3} \mathrm{CN}, 76 \%$, e) $\mathrm{NaHCO}_{3}, i-\mathrm{PrOH}-\mathrm{H}_{2} \mathrm{O}, 66 \%$.

ブチルハイポクロライトを用いて 83 のインドール の 3 位を塩素化しクロロインドレニン 84 としたの ち，合成により供給したビンドリン $\mathbf{5 3}$ の存在下， トリフルオロ酢酸で処理することにより, 望みの立 体化学でビンドリンが導入された 85 を $96 \%$ の収率
で，しかも単一異性体として得ることに成功した。 続いてトリフルオロアセチル基，2- ニトロベンゼ ンスルホニル基（Ns 基）を除去し，最後にピペリ ジン環の構築を行うことにより $(+)$ - ビンブラス チン $(\mathbf{5 2})$ の全合成を達成した. ${ }^{17)}$ 得られた各種スペ クトルデータは, 天然物のものと完全に一致した。 以上のように，新規インドール合成法を基盤として ビンドリンの効率的な合成法を確立し, さらに, ビ ンブラスチンの立体選択的な全合成を達成すること ができた.

2. チオールエステルを用いた，アルデヒド，ケ トンの合成法

カルボン酸及びその誘導体からアルデヒド及びケ トンへの変換は，有機合成上重要な反応である。一 般にエステルをアルコールの副生なしに選択的にア ルデヒド, 又は, ケトンに変換するのは困難であ り，隣接するへテロ元素官能基の関与がある場合な どのみに限られる，そこで，その選択的な変換のた めにこれまで様々な手法が開発されてきた. ${ }^{26)}$ その 中で, 最も多用されている手法の 1 つはカルボン酸 をヒドロキサム酸誘導体に変換し，それに対して $i$ $\mathrm{Bu}_{2} \mathrm{AlH}$ 又は Grignard 試薬などの炭素求核剤を作 用させて，アルデヒド，ケトンを選択的に得る方法 である. ${ }^{27)}$ その他, 酸クロライドを Pd 触媒の存在 下スズ試薬と反応させることによっても，対応する

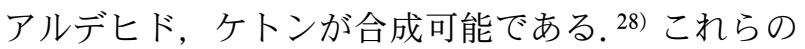
手法は，選択的に望みの化合物を与える優れた手法 であるが, $i-\mathrm{Bu}_{2} \mathrm{AlH}$ や Grignard 試薬などの塩基性 及び求核性の高い試薬を必要とする点, 又は, 比較 的不安定な酸クロライドを調製する必要があるな ぞ，複雑な化合物を合成するために必要な官能基の 共存性が必ずしも高くない.

一方我々のグループでは，以前に，チオールエス テルからアルデヒドへの極めて穏和な還元条件を見 い出している. ${ }^{29)}$ すなわち, エタンチオールエステ ルに対して, パラジウム炭素の存在下, トリエチル シランを作用させることで室温下速やかに対応する アルデヒドが得られるものである（Scheme 19）。 穏和な条件ゆえに官能基の共存性は極めて高く, 例 えば， $\alpha$-アミノ酸 86 より簡便に得られるチオール エステル87 からは, ラセミ化することなしに対応

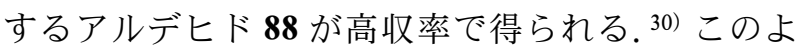
うに高い官能基共存性を生かして, 本反応は様々な 


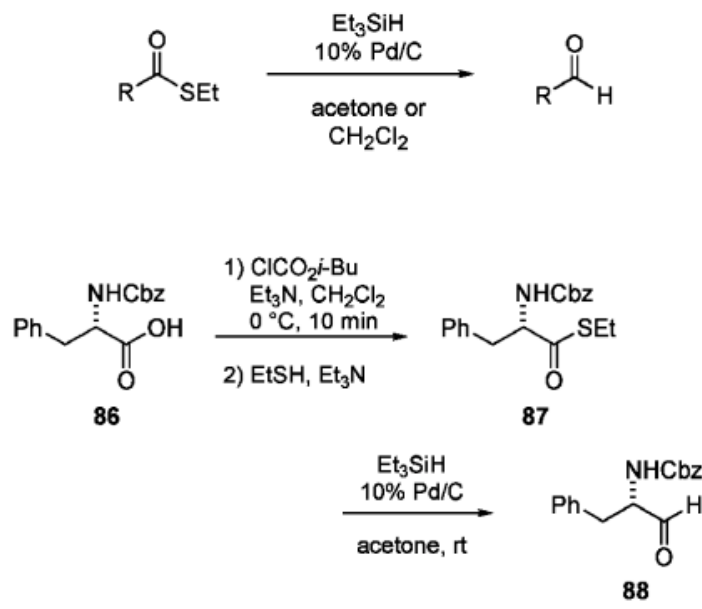

Scheme 19. Reduction of Thiol Esters to Aldehydes

複雑な構造の天然物の全合成において利用されてい る. ${ }^{31-36)}$

2-1. 有機亜鉛試薬を用いた新規ケトン合成法 本反応の反応メカニズムとしては，まず， 0 価のパ ラジウム $(\mathbf{8 9})$ が $\mathrm{C}-\mathrm{S}$ 結合に挿入しアシルパラジウ ム種 $(\mathbf{9 1})$ が生成したのち, トリエチルシラン $(\mathbf{9 2})$ と の金属交換，最後に $\mathrm{Pd}$ の還元的脱離によってアル デヒド $(\mathbf{9 4})$ が生成するとともに Pd（0）が再生する 触媒機構を考えている（Scheme 20）。ここで我々 は, トリエチルシラン $(\mathbf{9 2})$ のかわりに適当な有機金 属種を用いれば，金属交換反応，還元的脱離を経て 対応するケトンが得られるのではないかと考えた。 そこで，種々の有機金属種を用いた検討を開始した。

その結果, アルキル亜鉛試薬が望みのケトンを良 好な収率で与えることが判明した。 ${ }^{37)}$ すなわち，千 オールエステル $(\mathbf{9 5})$ を触媒量の $\left(\mathrm{PPh}_{3}\right)_{2} \mathrm{PdCl}_{2}$ の存 在下, EtZnI で処理すると室温 5 分で対応するエチ ルケトン (96)が 91\%の収率で得られた（Table 2)。 なお，触媒なしで反応を行った場合，室温 15 時間 後においてもケトンの生成はわずか $7 \%$ ありり原料 (95)が $83 \%$ 回収された。また, 市販の $\mathrm{Et}_{2} \mathrm{Zn}$ を用 いて反応を行った際には，望みのケトンが $70 \%$ 程 度の収率で得られたものの, アルデヒドの副生が見 られた。

上記の結果を受けて, 本反応の一般性を調べるべ く, 種々のチオールエステルを合成し反応を行った (Table 3)。その結果，アルキルに加え，芳香族， 及び $\alpha, \beta$ - 不飽和カルボン酸由来の基質でも反応が 進行した. さらに, ケトン, エステル, アルデヒド

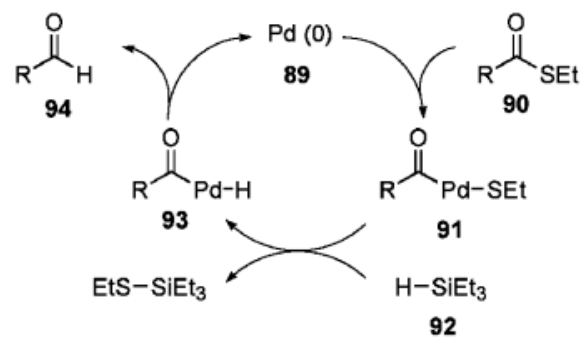

Scheme 20. Possible Reaction Mechanism

Table 2. Pd-Mediated Ketone Formation

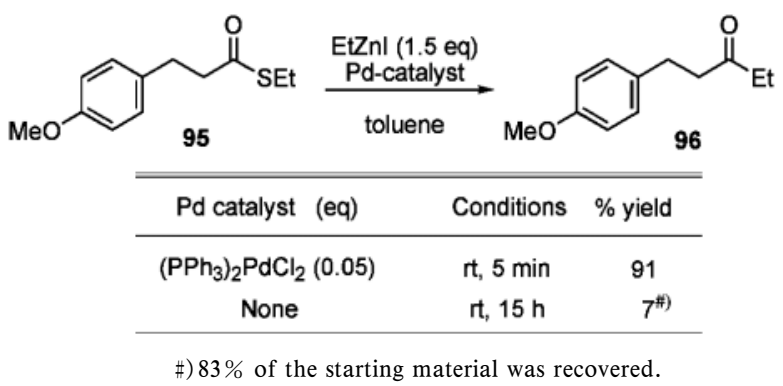

Table 3. Reaction with Various Thiol Esters

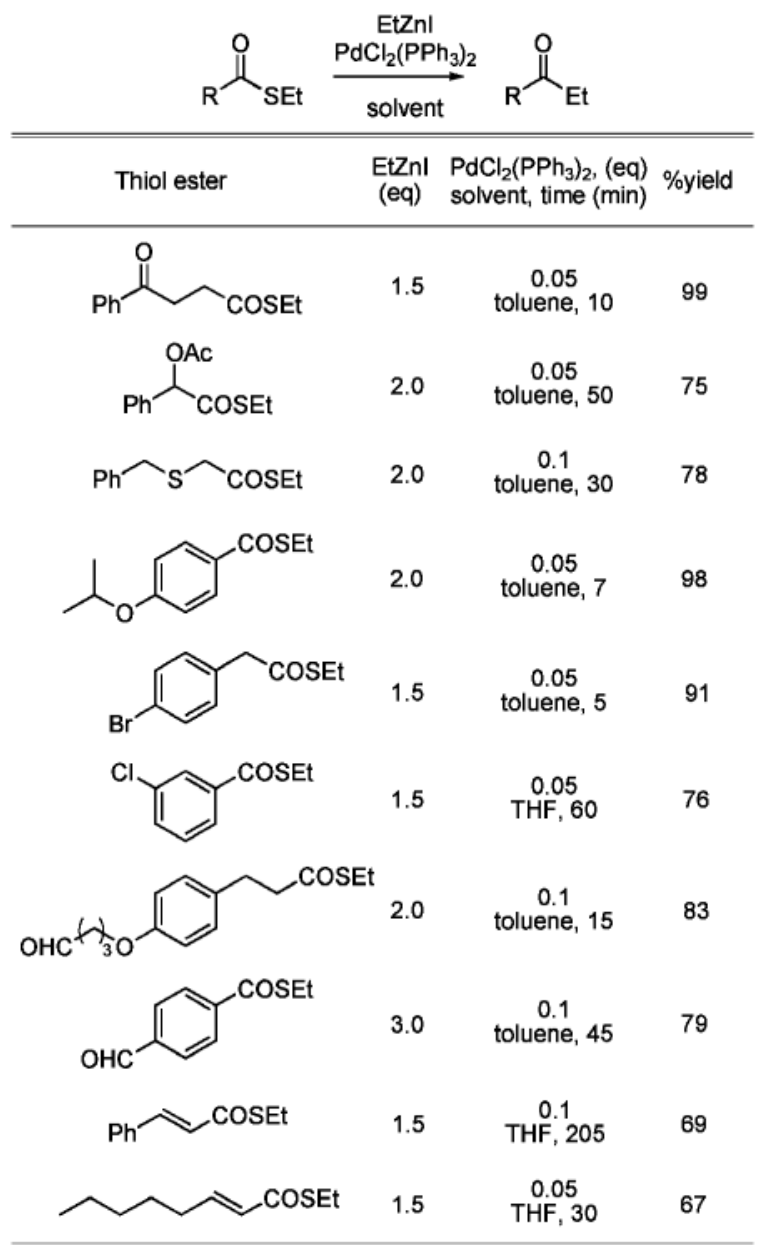


など，求核剤に対して反応性の高い官能基を有する 基質でもチオールエステル選択的に反応が進行し た。また，芳香族ブロム基も保持したままケトン形 成反応が進行した.

一方，亜鉛試薬の側についても様々なものが利用 できる (Table 4)。アルキル，ベンジル，フェニ ル，ビニル亜鉛試薬がそれぞれ対応するケトンを良 好な収率で与えた。また，亜鉛試薬の特徵の 1 つ は，それ自身反応性があまり高くないことから，官 能基を有する試薬の調製が可能なことである．本反 応においても，エステル，保護されたアミンを有す る亜鉛試薬を用いることができた.

さらに，本反応を $\alpha-ア ミ ノ$ 酸由来のチオールエ ステルを用いた $\alpha$-アミノケトンの合成へと応用し た（Table 5)。その結果，フェニルアラニン，グル タミン酸，プロリン由来の誘導体のいずれを用いて も，光学純度の低下なしに望みのケトンが生成し た。様々な構造の亜鉛試薬との組み合わせにより， 幅広い光学活性 $\alpha$ - アミノケトンを合成することが できた。

\section{2-2. アルキニルケトン合成法＼cjkstart亜鉛試薬を用}

Table 4. Reaction with Various Zinc Reagents

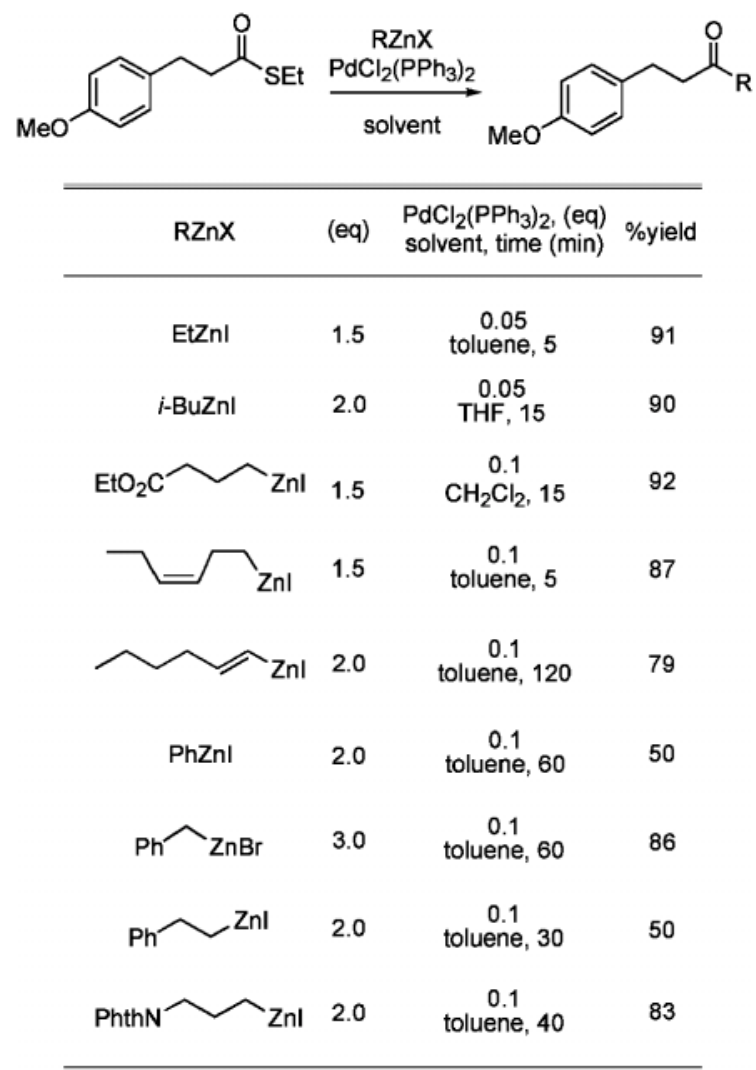

いたケトン合成法の開発の成功を受けて，次に薗頭 カップリング反応を基にしたアルキニルケトンの合 成法の検討を行った. ${ }^{38)}$ 1-ヘキシンをモデル基質と して用いて，典型的な䄇頭反応の反応条件，すなわ ち, $\mathrm{PdCl}_{2}\left(\mathrm{PPh}_{3}\right)_{2}$ とヨウ化銅の存在下, トリエチ ルアミン -DMF の混合溶媒系を用いたところ，望 みのアルケニルケトンは得られたものの $17 \%$ と低 収率にとどまった（Table 6)。種々検討の結果，反 応系中にフォスフィンリガンドを添加することで, 反応速度, 収率ともに大きく改善されることを見い 出した。最終的には，触媒として $\mathrm{PdCl}_{2}(\mathrm{dppf})$ を, リガンドとして P (2-furyl) ${ }_{3}$ 用いることで収率を 87\%にまで向上させることができた.

次に，上記最適条件を用いて，種々の末端アルキ ンとの反応を行った（Table 7). その結果，アルキ ル，フェニルアセチレンに加えて，保護したプロパ ルギルアルコール，シリルアセチレンなどを用いる ことができた，さらに，セリンから誘導した多官能 基性アセチレンの導入も高収率で進行した。

また，チオールエステル側に関しても $\alpha, \beta$ - 不飽 和カルボン酸由来の化合物及び安息香酸誘導体がそ れぞれ良好な収率で望みのカップリング体を与え,

Table 5. Synthesis of $\alpha$-Amino Ketones
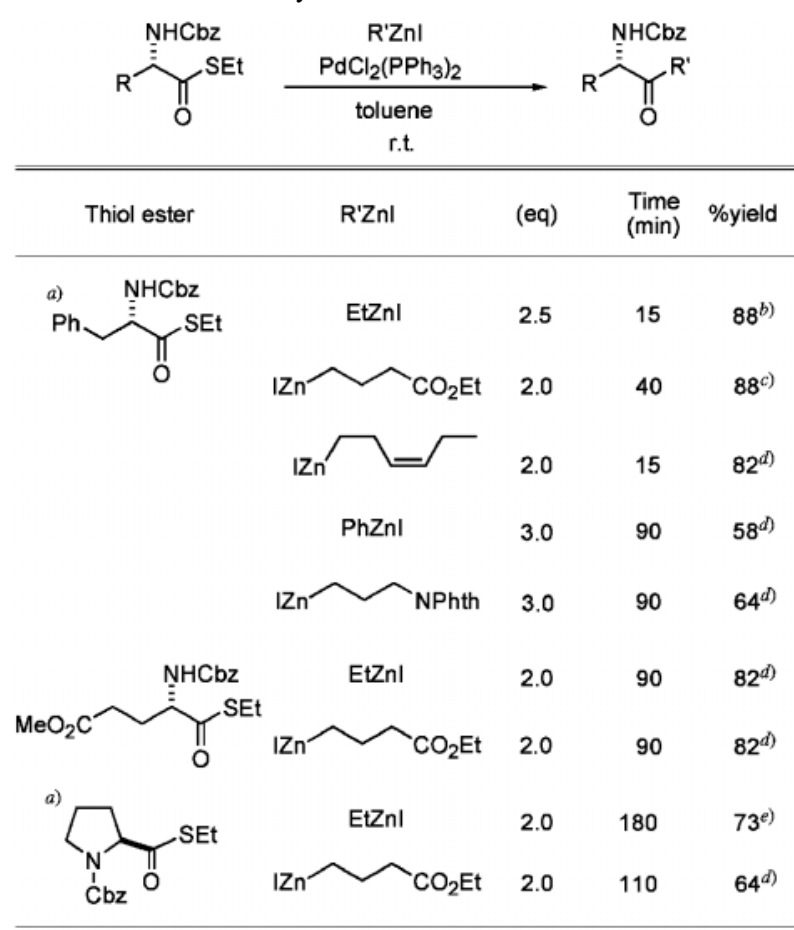

a) The ee were determined to be $>99 \%$. b) $99 \%$ ee. $c$ ) $98 \%$ ee. $d$ ) The ee of the products were not determined. $e$ ) $>99 \%$ ee, $[\alpha]^{22} \mathrm{D}-43.8^{\circ}(c$ $\left.1.26, \mathrm{CHCl}_{3}\right)$. 
Table 6. Optimization of Reaction Conditions

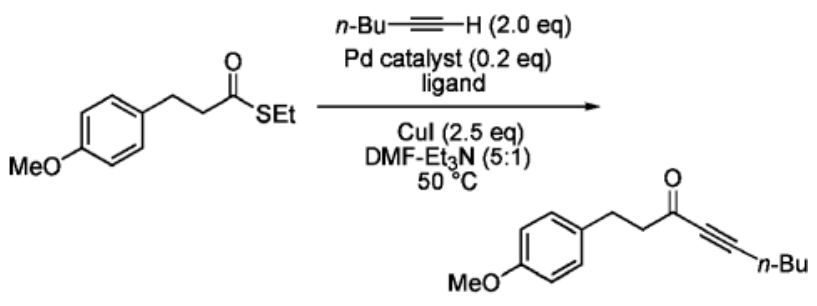

\begin{tabular}{lccc}
\hline \hline Pd catalyst & Phosphine (eq) & Time (h) & Yield (\%) ${ }^{a)}$ \\
\hline $\mathrm{PdCl}_{2}\left(\mathrm{PPh}_{3}\right)_{2}$ & none & 13 & 17 \\
& $\mathrm{PPh}_{3}(0.5)$ & 7 & 60 \\
& $\mathrm{P}(2 \text {-furyl })_{3}(0.5)$ & 6 & 64 \\
$\mathrm{PdCl}_{2}$ (dppf) & none & 5 & 34 \\
& $\mathrm{PPh}_{3}(2.0)$ & 11 & $72^{b)}$ \\
& $\mathrm{P}(2 \text {-furyl })_{3}(0.5)$ & 3 & 87 \\
\hline
\end{tabular}

a) Reaction in $0.2 \mathrm{M}$ solution on $0.1 \mathrm{mmol}$ scale. $b$ ) Reaction at room temperature.

Table 7. Reaction with Various Terminal Alkynes

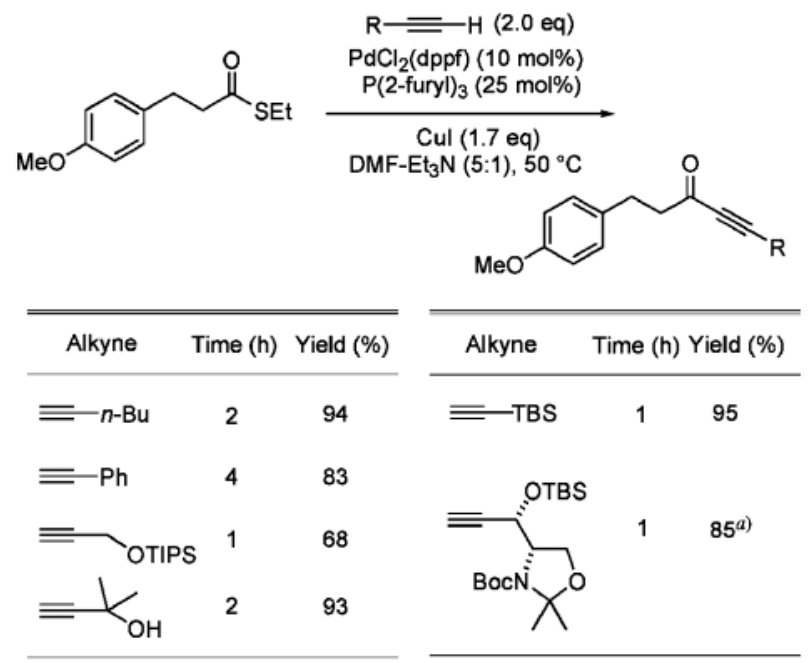

a) 1.2 equivalent of the alkyne was used.

ケトン, 芳香族ブロマイドなどが反応条件下損なわ れることがなかった（Table 8).

本反応の場合には, アシルパラジウム種に対して 銅アセチリドが金属交換反応を起こし，銅スルフィ ド錯体が生成するものと考えられる。したがつて, 反応の完結には 1 当量以上のヨウ化銅が必要であ り, また, 反応後のチオールは安定な銅スルフィド 錯体の形で捕捉されるので，チオールによる触媒の 被毒化が起こらないものと考えられる.

以上のように, チオールエステルのパラジウム炭 素とトリエチルシランによるアルデヒドへの還元反 応を出発点として, 反応メカニズムを基にしたアプ ローチによって，有機亜鉛試薬を用いたケトンの合
Table 8. Reaction with Various Thiol Esters

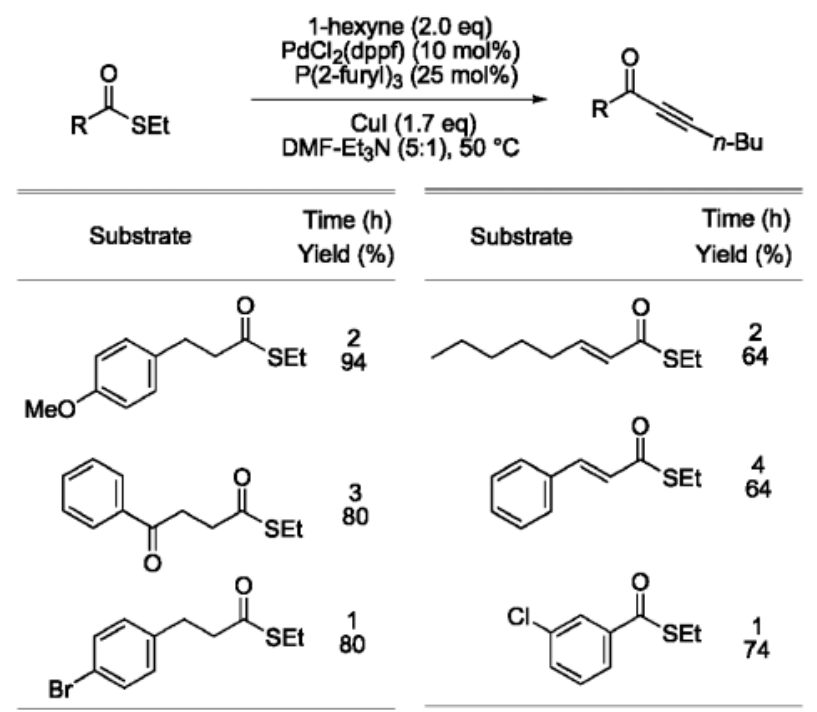

成法及び，末端アセチレンとの新規カップリング反 応を開発することができた。 これら反応の特徵は, いずれも，チオールエステル選択的に望みの反応の みが進行し, 官能基の共存性が極めて高い点であ る.したがって，様々な官能基を有する複雑なチ オールエステルを用いても，ピンポイントでの官能 基変換が可能であり，合成経路の短縮や，合成の終 盤での幅広い誘導体の合成に極めて有用であると考 えられる. 最後に, 本合成反応を用いた天然物全合 成の例を紹介したい.

\section{2-3. ケトン合成法を用いたビオチンの全合成} (+) - ビオチン $(97)$ は，ヒトや動物の栄養学的な見 地から, また, 特に最近では生物化学におけるツー ルとして重要な役割を示している化合物である。こ れまで，多くの合成経路が開発されているが, ${ }^{39)}$ 最 近田辺製薬の関らは，これまでの研究により合成法 が確立されているチオラクトン $(\mathbf{9 8})$ に対して我々の ケトン合成法を応用し，効率的な合成法を確立する ことに成功している（Scheme 21）.40)すなわち， $\mathrm{Pd}$ 触媒の存在下 98 に対して亜鉛試薬を作用させる と, ケトンの生成ののちに遊離のチオラートアニオ ンがケトンに付加してへミチオアセタール 99 を形 成する. この化合物を酸性条件下処理すると脱水生 成物 100 が得られ, 接触還元により側鎖の立体化学 が制御された 101 が得られる。常法にしたがって数 段階の変換により脱保護を行い, ビオチン $(\mathbf{9 7})$ の簡 便な全合成を達成している，亜鉛試薬を用いる我々 


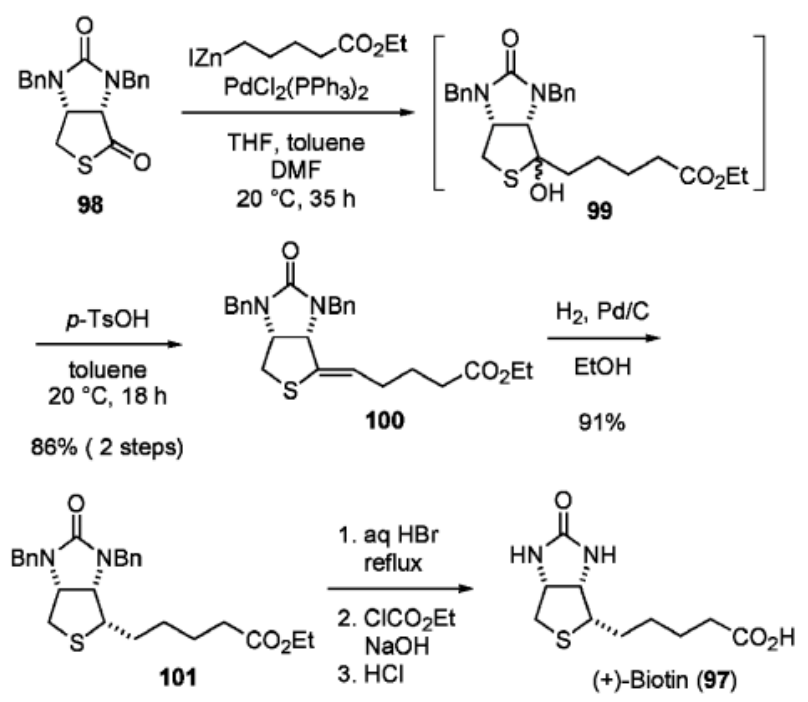

Scheme 21. Total Synthesis of (+)-Biotin (Seki et al.)

の反応によりエステルを有する側鎖の導入が可能と なり，これまでの Grignard 試薬などを用いた合成 経路と比較して工程数の短縮に成功している.

2-4. ケトン合成法を用いたフォモイドライド B の全合成フォモイドライドB (102) はファイ ザー製薬の金子らにより単離構造決定された ${ }^{41)}$ 化合 物であり，その特異な構造とファルネシル転移酵素 阻害活性などの興味深い活性を示すことから注目さ れている化合物である. ${ }^{42,43)}$ 筆者らが所属するグ

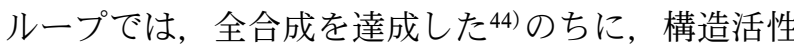
相関の解明を視野に入れた新たな合成経路の確立を 目的として検討を続けている，特に，生理活性発現 に大きな影響を与えると予想される長鎖側鎖部分に 注目し，合成の終盤に側鎖の導入が可能なルートの 検討を行った，その結果，我々のケトンの合成法が 合成終盤での側鎖の導入に極めて有効であることが 分かった (Scheme 22)。すなわち，無水マレイン 酸部位，ラクトンヘミケタールなど，求核剤に対し て不安定な複数の官能基を有する複雑なチオールエ ステル (103)に対してもケトン形成反応は官能基選 択的に進行し， $t$-Bu エステルのカルボン酸への変 換を経てフォモイドライド B の合成に成功してい る. ${ }^{45)}$ また, EtZnI を用いてより単純な誘導体の合 成も行っている.

\section{3. おわりに}

以上，新しい反応の開発とそれらを用いた天然物 の全合成について述べてきた。全合成の困難な点 は, 既存の反応の組み合わせや類縁化合物の合成経
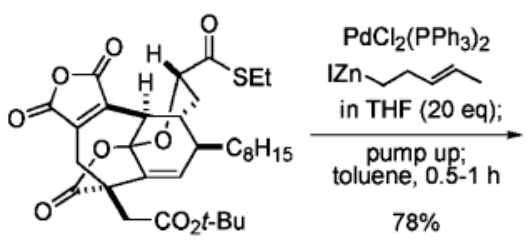

103

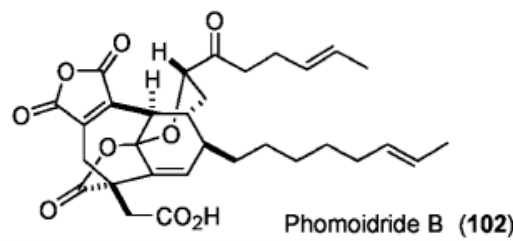

Scheme 22. Improved Total Synthesis of Phomoidride B (Fukuyama et al.)

路の応用では必ずしも効率的な合成が達成できると は限らないことである。例えば，1つの官能基の有 無で適用可能な反応が大きく制限を受け，特に官能 基の増える合成の終盤では避けられない問題とな る.さらに，個々の反応のみならず，合成全体のデ ザインも重要であり, 一般に, 直線的な合成経路よ りも，いくつかに分けたブロックを別々に合成し組 み合わせる収束的な合成経路の方が効率がよい。こ れらのことから，新たな官能基変換反応には官能基 の高い共存性が要求され，一方，骨格形成反応の場 合には官能基の共存性はもちろんのこと，収束的な 合成に適応できる汎用性が必要となる，ポストゲノ ムの時代を迎え，生命現象の解明やそれらを基にし た医薬の開発の場面で，有機化学による真の物質供 給の役割が益々重要となってきている。今後も，有 機合成化学の力量の向上に向けた反応開発を行うと ともに新たな合成コンセプトの提示を行って行きた い.

謝辞本研究は東京大学大学院薬学系研究科天 然物合成化学教室で行われたものであり, 研究の機 会を与えて下さり, また, 日頃より有益なご助言を 賜りました，福山 透教授に厚く感謝致します。ま た, 日々の弛まぬ努力により研究を推し進めて頂き ました，共同研究者の諸氏にも御礼申し上げます。 併せて, 研究を財政的な面からサポートして頂きま 
した，科学技術振興事業団（CREST, PRESTO),

三菱財団, 三菱化学研究奨励基金, 上原記念生命科 学財団, 興和生命科学振興財団, 文部科学省に感謝 致します。

\section{REFERENCES}

1) Joule J. A., "Indole and Its Derivatives, Science of Synthesis: Houben-Weyl Methods of Molecular Transformations," ed. by Thomas E. J., Georg Thieme Verlag, Stuttgart, 2000, Category 2, Vol. 10, Chapter 10.13., and references cited therein.

2) Fukuyama T., Chen X., Peng G., J. Am. Chem. Soc., 116, 3127-3228 (1994).

3) Kobayashi S., Peng G., Fukuyama T., Tetrahedron Lett., 40, 1519-1522 (1999).

4) Kobayashi S., Ueda T., Fukuyama T., Synlett, 883-886 (2000).

5) Tokuyama H., Fukuyama T., Chem. Rec., 2, 37-45 (2002).

6) Kobayashi Y., Fukuyama T., J. Heterocycl. Chem., 35, 1043-1055 (1998).

7) Tokuyama H., Watanabe M., Hayashi Y., Kurokawa T., Peng G., Fukuyama T., Synlett, 1403-1406 (2001).

8) Tokuyama H., Kaburagi Y., Chen X., Fukuyama T., Synthesis, 429-434 (2000) .

9) Sumi S., Matsumoto K., Tokuyama H., Fukuyama T., Org. Lett., 5, 1891-1893 (2003).

10) Synder H. R., Strohmayer H. F., Mooney R. A., J. Am. Chem. Soc., 80, 3708-3710 (1958).

11) Yates P., MacLachlan F. N., Rae I. D., Rosenberger M., Szabo A. G., Willis C. R., Cava M. P., Behforouz M., Lakshmikantham M. V., Zeigler W., J. Am. Chem. Soc., 95, 7842-7850 (1973).

12) He F., Bo Y., Altom J. D., Corey E. J., J. Am. Chem. Soc., 121, 6771-6772 (1999).

13) Kan T., Fukuyama T., J. Syn. Org. Chem. Jpn., 59, 779-789 (2001).

14) Tokuyama H., Yamashita T., Reding M. T., Kaburagi Y., Fukuyama T., J. Am. Chem. Soc., 121, 3791-3792 (1999).

15) Reding M. T., Kaburagi Y., Tokuyama H., Fukuyama T., Heterocycles, 56, 313-330 (2002).
16) Reding M. T., Fukuyama T., Org. Lett., 1, 973-976 (1999)

17) Yokoshima S., Ueda T., Kobayashi S., Sato A., Kuboyama T., Tokuyama H., Fukuyama T., J. Am. Chem. Soc., 124, 2137-2139 (2002).

18) For a review on medicinal chemistry of vinblastine, see: "Antitumor Bisindole Alkaloids from Catharanthus roseus (L.). The Alkaloids," eds. by Brossi A., Suffness M., Academic Press Inc., San Diego, 1990, Vol. 37, Chapters 3 and 4, pp. 133-204.

19) For a review on synthetic studies of vinblastine, see: "Antitumor Bisindole Alkaloids from Catharanthus roseus (L.). The Alkaloids," eds. by Brossi A., Suffness M., Academic Press Inc., San Diego, 1990, Vol. 37, Chapter 2, pp. 77-131.

20) Mangeney P., Andriamialisoa R. Z., Langlois N., Langlois Y., Potier P., J. Am. Chem. Soc., 101, 2243-2245 (1979).

21) Kutney J. P., Choi L. S. L., Nakano J., Tsukamoto H., McHugh M., Boulet C. A., Heterocycles, 27, 1845-1853 (1988).

22) Kuehne M. E., Matson P. A., Bornmann W. G., J. Org. Chem., 56, 513-528 (1991).

23) Magnus P., Mendoza J. S., Stamford A., Ladlow M., Willis P., J. Am. Chem. Soc., 114, 10232-10245 (1992).

24) Tokuyama H., Sato M., Ueda T., Fukuyama T., Heterocycles, 54, 105-108 (2001)

25) Schill G., Priester C. U., Windhövel U. F., Fritz H., Tetrahedron, 43, 3765-3786 (1987).

26) For a review, see: O’Neill B. T., “Nucleophilic Addition to Carboxylic Acid Derivatives: Comprehensive Organic Synthesis," eds. by Trost B. M., Fleming I., Pergamon, Oxford, 1991, Vol. 1, Chapter 1.13, p. 397.

27) Nahm S., Weinreb S. M., Tetrahedron Lett., 22, 3815-3818 (1981).

28) Milstein D., Stille J. K., J. Org. Chem., 44, 1613-1618 (1979).

29) Fukuyama T., Lin S.-C., Li L., J. Am. Chem. Soc., 112, 7050-7051 (1990).

30) Tokuyama H., Yokoshima S., Lin S. C., Li L., Fukuyama T., Synthesis, 1121-1123 (2002).

31) Evans D. A., Black W. C., J. Am. Chem. Soc., 115, 4497- 4513 (1993). 
32) Evans D. A., Ng H. P., Rieger D. L., J. Am. Chem. Soc., 115, 11446-11459 (1993).

33) Morimoto Y., Iwahashi M., Nishida K., Hayashi Y., Shirahama H., Angew. Chem. Int. Ed. Engl., 35, 904-906 (1996).

34) Evans D. A., Trotter B. W., Côté B., Coleman P. J., Angew. Chem. Int. Ed. Engl., 36, 27412744 (1997).

35) Smith A. B. III, Chen S. S.-Y., Nelson F. C., Reichert J. M., Salvatore B. A., J. Am. Chem. Soc., 119, 10935-10946 (1997).

36) Fujiwara A., Kan T., Fukuyama T., Synlett, 1667-1669 (2000).

37) Tokuyama H., Yokoshima S., Yamashita T., Fukuyama T., Tetrahedron Lett., 39, 31893192 (1998).

38) Tokuyama H., Miyazaki T., Yokoshima S., Fukuyama T., Synlett, 1512-1514 (2003).

39) For a review, see: De Clercq P. J., Chem.
Rev., 97, 1755-1792 (1997).

40) Mori Y., Seki M., Heterocycles, 58, 125-127 (2002).

41) Dabrah T. T., Harwood H. J. Jr., Huang L. H., Jandovich N. D., Kaneko T., Li J.-C., Lindsey S., Mosier P. M., Subashi T. A., Therrien M., Watts P. C., J. Antibiot., 50, 17 (1997)

42) For a review on Ras farnesyl transferase, see: Leonard D. M., J. Med. Chem., 40, 29712990 (1997).

43) For a review on the total syntheses, see: Spiegel D. A., Njardarson J. T., McDonald I. M., Wood J. L., Chem. Rev., 103, 2691-2728 (2003).

44) Waizumi N., Itoh T., Fukuyama T., J. Am. Chem. Soc., 122, 7825-7826 (2000).

45) Hayashi Y., Itoh T., Fukuyama T., Org. Lett., 5, 2235-2238 (2003). 